Eur. J. Mineral.

2019, 31, 823-836

Published online 14 June 2019

To Christian Chopin, for 30 years of dedicated service to EJM

\title{
Fluorcarmoite-(BaNa), the first Mg-dominant mineral of the arrojadite group
}

\author{
Fernando CÁMARA ${ }^{1, *}$, Erica BitTARELlO ${ }^{2}$, Marco E. CIRIOTTI $^{3}$, Fabrizio NESTOLA $^{4}$, \\ FRANCESCO RADICA ${ }^{5}$, FEDERICO MASSIMI ${ }^{6}$ and RoBERTo BRACCO ${ }^{7}$
}

${ }^{1}$ Dipartimento di Scienze della Terra “A. Desio”, Università degli Studi di Milano,

Via Mangiagalli 34, 20133 Milano, Italy

*Corresponding author, e-mail: fernando.camara@unimi.it

${ }^{2}$ SpectraLab s.r.l. - Spin-off accademico dell’Università degli Studi di Torino, Frazione Cappellazzo 84, 12062 Cherasco $(\mathrm{CN})$, Italy

${ }^{3}$ Associazione Micromineralogica Italiana, Via San Pietro 55, 10073 Devesi-Cirié, Torino, Italy

${ }^{4}$ Dipartimento di Geoscienze, Università degli Studi di Padova, Via Giovanni Gradenigo 6, 35131 Padova, Italy

${ }^{5}$ Dipartimento di Scienze, Università degli Studi Roma Tre, largo San Leonardo Murialdo 1, 00146 Roma, Italy

${ }^{6}$ Dipartimento di Ingegneria Meccanica e Industriale, Università degli Studi Roma Tre, Via della Vasca Navale 79, 00146 Roma, Italy

${ }^{7}$ Associazione Micromineralogica Italiana, Via Montenotte18/6, 17100, Savona, Italy

\begin{abstract}
Fluorcarmoite-(BaNa), ideally ${ }^{A 1} \mathrm{Ba}^{A 2} \square^{B 1,2} \mathrm{Na}^{\mathrm{Na1}, 2} \mathrm{Na}_{2}{ }^{\mathrm{Na}} \square^{C a} \mathrm{Ca}^{M} \mathrm{Mg}_{13} \mathrm{Al}\left(\mathrm{PO}_{4}\right)_{11}\left(\mathrm{PO}_{3} \mathrm{OH}\right)^{W} \mathrm{~F}_{2}$, was found in a pebble of the riverbed of the upper Maremola Creek, close to the village of Isallo, in the Magliolo municipality (Savona, Liguria, Italy). The root-name is after Monte Carmo di Loano, the highest peak in the area, namesake of the tectonic unit where the mineral was found and the first locality where phosphate mineralization has been found in the region. The mineral is associated with quartz and almandine and has microscopic inclusions of fluorapatite and possible graftonite. It occurs as yellow-orange and translucent crystals in an anhedral centimetric nodule embedded in quartz. Fluorcarmoite-(BaNa) is brittle, and no cleavage or parting was observed. It has a yellow-orange streak, a vitreous lustre, does not fluoresce under shortwave or longwave ultraviolet light and is weakly pleochroic (light yellow). Fluorcarmoite-(BaNa) is optically biaxial positive, with $\alpha=1.6240(5), \beta=1.6255(5), \gamma=1.6384(5)$ $(589 \mathrm{~nm}), 2 V_{\text {meas }}=35(2)^{\circ}$ and $2 V_{\text {calc }}=37.9^{\circ}$. Raman spectroscopy shows the presence of weak bands in the $\mathrm{OH}$-stretching region. The average chemical composition is (wt\%, wavelength-dispersive-mode electron microprobe): $\mathrm{Na}_{2} \mathrm{O} 5.83, \mathrm{~K}_{2} \mathrm{O} 0.36, \mathrm{CaO} 2.64$, $\mathrm{SrO} 0.46, \mathrm{BaO} 7.12, \mathrm{MnO} 2.01, \mathrm{FeO} 17.68, \mathrm{MgO} 15.12, \mathrm{Al}_{2} \mathrm{O}_{3}$ 2.57, $\mathrm{P}_{2} \mathrm{O}_{5} 44.96, \mathrm{~F} 2.14,-\mathrm{O}=\mathrm{F}_{2} 0.90, \mathrm{H}_{2} \mathrm{O}_{\text {calc }} 0.33$, total 100.32. The empirical formula calculated on the basis of $50 \mathrm{O}+\mathrm{F}+(\mathrm{OH})$ atoms per formula unit (apfu), is: $\left(\mathrm{Na}_{3.77} \mathrm{Ca}_{0.94} \mathrm{Ba}_{0.93}\right.$ $\left.\mathrm{K}_{0.15} \mathrm{Sr}_{0.09} \square_{0.12}\right)_{\Sigma=6.00}\left(\mathrm{Mg}_{7.52} \mathrm{Fe}_{4.93}^{2+} \mathrm{Mn}_{0.57}^{2+}\right)_{\Sigma=13.02} \mathrm{Al}_{1.01}\left(\mathrm{PO}_{4}\right)_{11}\left(\mathrm{PO}_{3}\right)\left(\mathrm{OH}_{0.74} \mathrm{~F}_{0.26}\right) \mathrm{F}_{2}$. Strongest lines in the X-ray powder diffraction

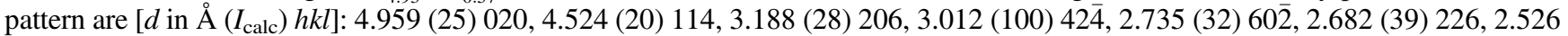
(25) 424 . The crystal structure has been refined using single-crystal X-ray diffractometer data $\left(R_{\text {int }}=4.1 \%\right)$ in space group $C c$ (no. 14) to $R_{1}=0.0342$ for 11511 reflections with $F_{\mathrm{o}}>4 \sigma|F|$ and 0.0417 for all 13232 data. Refined unit-cell parameters are: $a=16.4013(3) \AA, b=9.9487(1) \AA, c=24.4536(8) \AA, \beta=105.725(2)^{\circ}, V=3840.80(15) \AA^{3}(Z=4)$. Fluorcarmoite-(BaNa) is the first $\mathrm{Mg}$-dominant mineral of the arrojadite group. $\mathrm{Mg}$ orders preferentially in the $M 1, M 2 \mathrm{~b}, M 3 \mathrm{a}, \mathrm{b}, M 4 \mathrm{a}, \mathrm{b}$ and $M 7 \mathrm{a}$, b sites whereas the non-dominant $\mathrm{Fe}^{2+}$ and very minor $\mathrm{Mn}^{2+}$ show site preference for $M 2 \mathrm{a}, M 5 \mathrm{a}, \mathrm{b}$ and $M 6 \mathrm{a}, \mathrm{b}$. The $A 1$ site is mostly populated by $\mathrm{Ba}$, the $A 2$ site is empty, and minor $\mathrm{Fe}^{2+}$ occurs at the $\mathrm{B} 1 \mathrm{~b}$ site. A significant, but not dominant occupancy of the Na3 site by Na is also observed. Only $\mathrm{Ca}$ and $\mathrm{Al}$ are present at the $\mathrm{Ca}$ and $\mathrm{Al}$ sites, respectively. The type material is deposited in the mineralogical collection of the Museo Regionale di Scienze Naturali di Torino, Sezione di Mineralogia, Petrografia e Geologia, Torino (Italy). The mineral and its name have been approved by the IMA-CNMNC (2015-062).
\end{abstract}

Key-words: arrojadite-group minerals; fluorcarmoite-(BaNa); crystal structure, new mineral; new mineral; phosphate; Monte Carmo; Italy.

\section{Introduction}

Arrojadite-group minerals occur typically as primary minerals in granitic pegmatites. They are frequent in Lithium-Cesium-Tantalum (LCT) pegmatites belonging to the beryl-"columbite"-phosphate subtype (in the classification of Černý \& Ercit, 2005), e.g. Eagle et al. (2015),
Vignola et al. (2016) and Birch (2018). Arrojadite-group minerals occur also associated with quartz related to hydrothermal activity accompanying a high-phosphorus, extremely fractionated topaz-"zinnwaldite" leucogranite in the Gemerská Poloma area (Košice Region, Slovak Republic; Števko et al., 2015, 2018). Arrojadite-group minerals are also reported in sedimentary rocks, as in northwestern 
Yukon Territory, Canada (Robertson, 1982; Young \& Robertson, 1984; Robinson et al., 1992; Tomes et al., 2018), although this is a unique locality.

The space group of dickinsonite was given by Wolfe (1941) as $C 2 / c$. The space group $C 2 / m$ was chosen for arrojadite from the Nickel Plate mine (South Dakota, USA) by Lindberg (1950) and later as $A 2_{1} / n$ by Fisher (1965). The structure of arrojadite-group minerals was first determined on a sample from the Nickel Plate mine (Keystone, South Dakota) by Krutik et al. (1979) using the space group $B 2 / b$, a further choice of the space group 15 by Merlino et al. (1981) as C2/c, Moore et al. (1981) as $A 2 / a$ and Demartin et al. (1996) as $C 2 / c$.

The crystal-chemistry of the arrojadite group was reinvestigated by Cámara et al. (2006) and Chopin et al. (2006), who described the structure in the non-centrosymmetric space group $C c$ and established a new classification scheme for the group based on the general formula $\mathrm{A}_{2} \mathrm{~B}_{2} \mathrm{CaNa}_{2+\mathrm{x}}$ $\mathrm{M}_{13} \mathrm{Al}\left(\mathrm{PO}_{4}\right)_{11}\left(\mathrm{PO}_{3} \mathrm{OH}_{1-\mathrm{x}}\right) \mathrm{W}_{2}$, where: $\mathrm{A}$ corresponds to large divalent cations $(\mathrm{Ba}, \mathrm{Sr}, \mathrm{Pb})$ or monovalent cations $(\mathrm{K}, \mathrm{Na})(A 1$ site), and to monovalent cations $(\mathrm{Na})$ or vacancies ( $A 2$ site); $\mathrm{B}$ corresponds to small divalent cations (Fe, $\mathrm{Mn}, \mathrm{Mg}$ at the $B 1 \mathrm{~b}$ and $B 1 \mathrm{c}$ sites) and vacancies or monovalent $\mathrm{Na}$ cations (at the $B 1$ and $B 2$ sites); $\mathrm{Ca}$ is dominant (with minor $\mathrm{Sr}$ ) at the $\mathrm{Ca}$ site; $\mathrm{Na}$ is dominant at the $\mathrm{Na} 1$ and $\mathrm{Na} 2$ sites; $\mathrm{Na}$ can also occupy the site $\mathrm{Na3}$ if the third proton bonded to the acid phosphate group is not present $(x=1) ; M$ sites contain small divalent cations $\left(\mathrm{Fe}^{2+}\right.$, $\mathrm{Mn}^{2+}$ and $\mathrm{Mg}$, with minor $\mathrm{Li}$ and $\mathrm{Zn}$ ); the $A l$ site can host $\mathrm{Fe}^{3+}$ and very minor amounts of $\mathrm{Ti}$ and $\mathrm{Sc}$; the $W$ site may be occupied by $\mathrm{OH}$ or $\mathrm{F}$. The mineral species of the group are then named by a root name plus three suffixes written within parentheses as extended Levinson modifiers and eventual prefixes. The root name is defined by the dominant divalent cation at the $M$ sites: arrojadite $(\mathrm{Fe})$, dickinsonite $(\mathrm{Mn})$, and in case of $\mathrm{Mg}$ dominance at $M$ sites, a further root-name was foreseen by Chopin et al. (2006). Regarding suffixes, following the rule of the dominant species of the dominant valence state, the first regards the dominance at the $A 1$ site (once $\mathrm{Ca}$ sites have been filled by $\mathrm{Ca}$ and divalent cations of increasing radius; the second is based on the occupancy of $B$ sites, which will depend on the excess at the $M$ sites $\left({ }^{M} \mathrm{Fe}^{*}=\mathrm{Fe}^{2+}+\mathrm{Mn}^{2+}+\mathrm{Mg}+\mathrm{Zn}+\right.$ $\mathrm{Li}-13=\Sigma M^{2+}+\mathrm{Li}-13$ ), and will be the dominant cation at the $M$ sites or Na in the case that ${ }^{M} \mathrm{Fe}^{*} \leq 0.5 p f u$; the third suffix is used when $x$ in the above formula is $>0.5$, meaning that the proton of the acid phosphate group is substituted by another ion (usually $\mathrm{Na}$ ). Regarding prefixes, these are used when there is an anion substitution at the $W$ sites (for instance, "fluor" if $(\mathrm{OH})$ is substituted by $\mathrm{F}$ ) and/or if there is a substitution of $\mathrm{Al}$ by $\mathrm{Fe}^{3+}$ at the $A l$ sites. After the classification of Chopin et al. (2006), two further members of the arrojadite group have been described: arrojadite-(BaNa) (Vignola et al., 2016) and fluorarrojadite-(BaNa) (Števko et al., 2018).

Fluorcarmoite-(BaNa) is the first arrojadite-group mineral in which $\mathrm{Mg}$ is dominant at the $M$ sites. Therefore, because $\mathrm{Mg}>\mathrm{Fe}$ and $>\mathrm{Mn}$, a new root name is warranted according to the nomenclature of the arrojadite group (Chopin et al., 2006). The new root-name is after Monte Carmo di Loano (Savona, Liguria, Italy), the locality where the sample was found. Monte Carmo is the highest peak in the area, and the first locality where phosphate mineralization was found in the region. The prefix "fluor" and suffix -(BaNa) follow the rules in Chopin et al. (2006), with an ideal formula ${ }^{A 1} \mathrm{Ba}^{A 2} \square^{B 1,2} \mathrm{Na}^{\mathrm{Na1}, 2} \mathrm{Na}_{2}{ }^{\mathrm{Na} 3} \square^{\mathrm{Ca}} \mathrm{Ca}^{M} \mathrm{Mg}_{13} \mathrm{Al}\left(\mathrm{PO}_{4}\right)_{11}\left(\mathrm{PO}_{3} \mathrm{OH}\right)^{W} \mathrm{~F}_{2}$ and charge arrangement \#3 of Chopin et al. (2006). The new mineral was approved by the International Mineralogical Association Commission on New Minerals, Nomenclature and Classification (IMA 2015-062). A fragment of the holotype material is deposited in the mineralogical collection of the Museo Regionale di Scienze Naturali di Torino, Sezione di Mineralogia, Petrografia e Geologia, via Giovanni Giolitti 36, I-10123 Torino (Italy), catalogue number M/15940.

\section{Geological setting and mineral occurrence}

The mineral occurs in the riverbed of the upper Maremola Creek, close to the village of Isallo, in the Magliolo municipality (Savona, Liguria, Italy; $\sim 44^{\circ} 11^{\prime} 37^{\prime \prime} \mathrm{N}, \sim 8^{\circ}$ $\left.15^{\prime} 1^{\prime \prime} \mathrm{E}\right)$. The locality is also known by mineral collectors as "Costa Balzi Rossi", after the overlying cliff where rich associations of rare-earth minerals have been found in recent years.

The Monte Carmo tectonic unit of the Briançonnais domain crops out in the area and includes a Permian metavolcanic basement ("Scisti di Gorra" schists, "Porfiroidi del Melogno" ignimbrites, "Formazione di $E z e$ " volcanic ash), followed by a Permo-Triassic cover starting with polygenic conglomerates ("Verrucano Brianzonese") and sedimentary quartzites ("Quarziti di Ponte di Nava"), underlying younger carbonate sequences. Fluorcarmoite-(BaNa) was found in an erratic rounded pebble in the riverbed of the Maremola Creek by one of the authors (RB) in 2012. The erratic pebble is related to phosphate-bearing quartzites occurring in the area, especially on nearby Monte Carmo di Loano (Boiteau, 1971; Cortesogno, 1984; Menardi Noguera, 1984; Cortesogno et al., 1987; Bracco \& Marchesini, 2016), which in turn are part of a thick horizon of quartzites sparsely occurring all over the Alpine range. The origin of phosphate mineralization is uncertain. At the Monte Carmo di Loano site, as well as most other Alpine localities, lazulite is the most widespread phosphate, but several less common phosphates have been reported (Bracco et al., 2007; Bracco \& Marchesini, 2016). The mineral is associated with quartz and almandine and has microscopic inclusions of fluorapatite and possible graftonite.

Other minerals found at the same locality, but not associated with fluorcarmoite-(BaNa), are: "adularia", aeschynite-(Y), albite, allanite-(Ce), anatase, bastnäsite$(\mathrm{Ce})$, brookite, cassiterite, cerussite, chernovite-(Y), churchite-(Y), clinochlore, fergusonite-(Y), gorceixite, goyazite, graftonite, hematite, hingganite-(Y), hundolmenite(Y), jarosite, lazulite, magnetite, mitridatite, monazite-(Ce), 
monazite-(La), paraniite-(Y), pyrite, pyrrothite, rhabdophane-(Nd), rutile, schorl-dravite tourmaline series, thortveitite, titanite, wulfenite and xenotime-(Y) (Bracco et al., 2006, 2007, 2009, 2012; Castellaro, 2014; Bracco \& Marchesini, 2016).

Fluorcarmoite-(BaNa), except for minor fluorapatite and possible graftonite inclusions, is the main phosphate observed in the type specimen and occurs as an anhedral centimetric nodule embedded in quartz, presumably syngenetic. Another arrojaditic phosphate of a different composition is associated with fluorcarmoite-(BaNa), but its volume is very small, and it will probably be impossible to characterize it. Its composition is much richer in $\mathrm{Ca}$.

The occurrence strongly resembles that of the type locality of arrojadite-(BaFe) at Alpe Groppera in the Central Alps, Sondrio Province, Lombardy, Italy (Demartin et al., 1996; Cámara et al., 2006; Chopin et al., 2006).

\section{Appearance and physical properties}

Fluorcarmoite-(BaNa) occurs as subhedral equant crystals, stout, more or less platy prisms $10-15 \mathrm{~mm}$ in size (Fig. 1) on compact quartz. The mineral is brittle, and no cleavage or parting was observed. Elastic modulus and hardness were measured with a Nano Indenter Agilent G200 in CSM mode (Continuous Stiffness Measurement; Oliver \& Pharr 1992, 2004), with a frequency of $45 \mathrm{~Hz}$, amplitude of oscillation $2 \mathrm{~nm}$, constant strain rate of $0.05 \mathrm{~s}^{-1}$; the range of displacement into surface for the average values elastic modulus and hardness is $50-100 \mathrm{~nm}$. Results of hardness and modulus profiles are: elastic modulus $147 \pm 3.6(\mathrm{GPa})$, hardness $12.12 \pm 0.47(\mathrm{GPa})$, Vickers hardness 1236 , Mohs $>7<8$. These values were obtained after averaging over five different tests. The Poisson's ratio is assumed to be 0.2 . Before and after the tests on the samples, tests on a standard sample of silica were done to calibrate the instrument.

Fluorcarmoite-(BaNa) has a yellow-orange streak, a vitreous lustre and does not fluoresce under shortwave or longwave ultraviolet light. Individual crystals are yelloworange in colour and translucent. Fluorcarmoite-(BaNa) is optically biaxial positive, with a $2 V_{\text {meas }}=35(2)^{\circ}$ (program ExcalibrW was used to process the extinction data and to determine the $2 \mathrm{~V}$ value; Gunter et al., 2005) and $2 V_{\text {calc }}=$ $37.9^{\circ}$. The measured refractive indices are $\alpha=1.6240(5)$, $\beta=1.6255(5), \gamma=1.6384(5)$ (589 nm). Refractive indices were determined by the double-variation method $(\mathrm{Su}$ et al., 1987; Gunter et al., 2005) using standard Cargille liquids as reference. Fluorcarmoite-(BaNa) is weakly pleochroic (light yellow to colourless).

Fluorcarmoite-(BaNa) is unreactive and insoluble in either $2 \mathrm{M} \mathrm{HCl}, 10 \% \mathrm{HCl}$ or $65 \% \mathrm{HNO}_{3}$. The measured density of is $3.40 \mathrm{~g} / \mathrm{cm}^{3}$ (Clerici solution). The calculated density obtained from the empirical formula and unit-cell parameters of the single crystal used for the crystal-structure determination is $3.394 \mathrm{~g} / \mathrm{cm}^{3}$. The mean refractive index $n$ of fluorcarmoite-(BaNa), the calculated density and the empirical formula obtained by electron microprobe (see below)

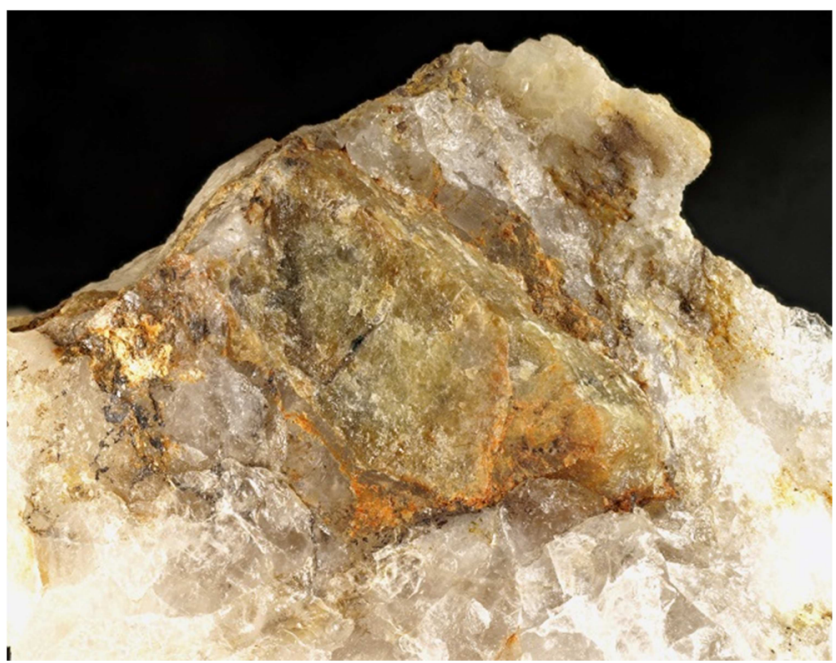

Fig. 1. Photograph of fluorcarmoite-(BaNa). Collection and photo R. Bracco (field of view $25 \mathrm{~mm}$ ).

yielded a Gladstone-Dale compatibility index (Mandarino, 2007) of 0.020 , rated as excellent.

\section{Chemical data}

\subsection{Electron microprobe}

The chemical composition was determined using a Cameca SX-50 electron microprobe operated in wavelengthdispersive (WDS) mode at CNR-IGG of Padova (installed at Department of Geosciences of University of Padova) on grains extracted from the holotype, close to the place where the crystal used for the diffraction study was extracted, embedded in epoxy resin and polished. Major and minor elements were determined at $15 \mathrm{kV}$ accelerating voltage and $10 \mathrm{nA}$ beam current (beam size $3 \mu \mathrm{m}$ ), with 40-20 s count time on both peak and background. Probe standards (spectral line; analysing crystal) were: Amelia albite $(\mathrm{NaK} \alpha$;

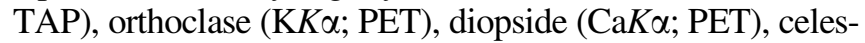
tine $\left(\mathrm{Sr} L \alpha\right.$; PET), baryte $(\mathrm{Ba} L \alpha ; \mathrm{LIF}), \mathrm{MnTiO}_{3}(\mathrm{MnK} \alpha$;

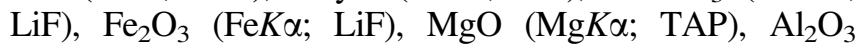

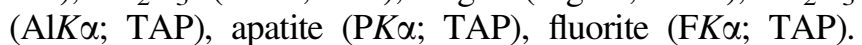
X-ray counts were converted to oxide wt $\%$ using the PAP correction program (Pouchou \& Pichoir, 1984, 1985). The crystals selected for study are compositionally homogeneous. Only sporadic inclusions of fluorapatite and possible graftonite were found in the sample. $\mathrm{H}_{2} \mathrm{O}$ was calculated on the basis of $3(\mathrm{OH})+\mathrm{F}$ groups pfu (Chopin et al., 2006). The average of 15 analyses is given in Table 1 . The amount of $\mathrm{P}_{2} \mathrm{O}_{5}$ analysed is higher than expected for $12 \mathrm{P}$ apfu. In fact, the normalized values lead to $12.27 \mathrm{P}$ apfu. This can be due just to intrinsic uncertainty that in the case of $c a .2 \%$ in $\mathrm{P}$ stoichiometry converts into 1.35 charge, i.e., more than a complete heterovalent substitution on any site. As a matter of fact these deviations from the ideal $\mathrm{P}$ content affect low-charge cation contents in a way that may prevent a correct classification (Chopin et al., 2006). In the case of normalization to $12 \mathrm{P}$ pfu (and $\mathrm{H}$ by charge balance), the 
Table 1. Analytical data (wt\%) for fluorcarmoite-(BaNa) (15 analytical points).

\begin{tabular}{lrcc}
\hline & Mean & Range & $S D$ \\
\hline $\mathrm{Na}_{2} \mathrm{O}$ & 5.83 & $5.48-6.18$ & 0.16 \\
$\mathrm{~K}_{2} \mathrm{O}$ & 0.36 & $0.30-0.45$ & 0.05 \\
$\mathrm{CaO}$ & 2.64 & $2.53-2.79$ & 0.08 \\
$\mathrm{SrO}$ & 0.46 & $0.20-0.64$ & 0.13 \\
$\mathrm{BaO}$ & 7.12 & $6.14-8.07$ & 0.55 \\
$\mathrm{MnO}$ & 2.01 & $1.69-2.33$ & 0.18 \\
$\mathrm{FeO}$ & 17.68 & $16.90-18.09$ & 0.29 \\
$\mathrm{MgO}$ & 15.12 & $14.84-15.46$ & 0.19 \\
$\mathrm{Al}_{2} \mathrm{O}_{3}$ & 2.57 & $2.48-2.76$ & 0.09 \\
$\mathrm{P}_{2} \mathrm{O}_{5}$ & 44.96 & $43.51-45.29$ & 0.42 \\
$\mathrm{~F}$ & 2.14 & $2.02-2.29$ & 0.00 \\
$\mathrm{Subtotal}^{\mathrm{O}} \equiv \mathrm{F}$ & 100.89 & $98.10-102.18$ & 0.98 \\
$\mathrm{H}_{2} \mathrm{O}^{* *}$ & 0.90 & $0.85-0.97$ & 0.03 \\
$\mathrm{Total}^{*}$ & 0.33 & $0.27-0.40$ & 0.04 \\
$\mathrm{P}_{2} \mathrm{O}_{5}{ }^{*}$ & 100.32 & $96.26-101.65$ & 1.43 \\
\hline
\end{tabular}

*Reduced to the $95 \%$ to obtain $12 \mathrm{P}$ apfu following recommendations in Chopin et al. (2006), see text.

**B By stoichiometry.

effect of small P errors on the sums of cations, and therefore on the number of vacancies, is amplified. Normalization using the analysed value produces a sum of $M$ sites $\left(\mathrm{Fe}^{2+}+\right.$ $\mathrm{Mn}^{2+}+\mathrm{Mg}$ ) of 12.58 apfu. Whereas this could be in agreement with the observed light site scattering at $M$ sites (see structure refinements results ahead), it would imply no $\mathrm{Fe}^{2+}$ left to be partitioned in $B 1$ sites, in contrast with results from refinement. Therefore, following recommendation by Chopin et al. (2006), a lower value of $\mathrm{P}_{2} \mathrm{O}_{5}$ was calculated and used to calculate the normalized mean analysis. Calculated value is reported in Table 1 . The empirical formula calculated on the basis of $50 \mathrm{O}+\mathrm{F}+(\mathrm{OH})$ apfu is then:
$\left(\mathrm{Na}_{3.77} \mathrm{Ca}_{0.94} \mathrm{Ba}_{0.93} \mathrm{~K}_{0.15} \mathrm{Sr}_{0.09} \square_{0.12}\right)_{\Sigma=6.00}\left(\mathrm{Mg}_{7.52} \mathrm{Fe}_{4.93}^{2+}\right.$ $\left.\mathrm{Mn}_{0.57}^{2+}\right)_{\Sigma=13.02} \mathrm{Al}_{1.01}\left(\mathrm{PO}_{4}\right)_{11}\left(\mathrm{PO}_{3}\right)\left(\mathrm{OH}_{0.74} \mathrm{~F}_{0.26}\right) \mathrm{F}_{2}$. The simplified formula is $\mathrm{BaNa}_{4} \mathrm{CaMg}_{13} \mathrm{Al}\left[\left(\mathrm{PO}_{4}\right)_{11}(\mathrm{OH})\left(\mathrm{PO}_{3}\right)\right]$ $\mathrm{F}_{2}$, which requires $\mathrm{Na}_{2} \mathrm{O} 6.92, \mathrm{BaO} 8.56, \mathrm{CaO} 3.13, \mathrm{MgO}$ 29.26, $\mathrm{Al}_{2} \mathrm{O}_{3}$ 2.85, $\mathrm{P}_{2} \mathrm{O}_{5}$ 47.55, F 2.12, $\mathrm{H}_{2} \mathrm{O}$ 0.50, total $100 \mathrm{wt} \%$.

\section{Micro-Raman spectroscopy}

The Raman spectrum of fluorcarmoite-(BaNa) (Fig. 2) was obtained using a micro/macro Jobin Yvon Model LabRam HRVIS, equipped with a motorized $x-y$ stage and an Olympus microscope. The backscattered Raman signal was collected with a $50 \times$ objective and the Raman spectrum was obtained for a randomly oriented crystal. The $632.8 \mathrm{~nm}$ line of a $\mathrm{He}-\mathrm{Ne}$ laser was used as excitation; laser power was controlled by density filters. The minimum lateral and depth resolution was set to a few $\mu \mathrm{m}$. The system was calibrated using the $520.6 \mathrm{~cm}^{-1}$ Raman band of silicon before each experimental session. The spectra were collected with multiple acquisitions (2-6) with single counting times ranging between 20 and $180 \mathrm{~s}$. Spectral manipulation such as baseline adjustment, smoothing and normalization were done using the LabSpec 5 software package (Horiba Jobin Yvon GmbH, 2004, 2005). After background removal, band-component analysis was done using the Fityk software package (Wojdyr, 2010), which enabled the type of fitting function to be selected and allows specific parameters to be fixed or varied accordingly.

\section{X-ray diffraction}

Experimental X-ray powder diffraction data were collected using an Oxford Gemini R Ultra diffractometer equipped

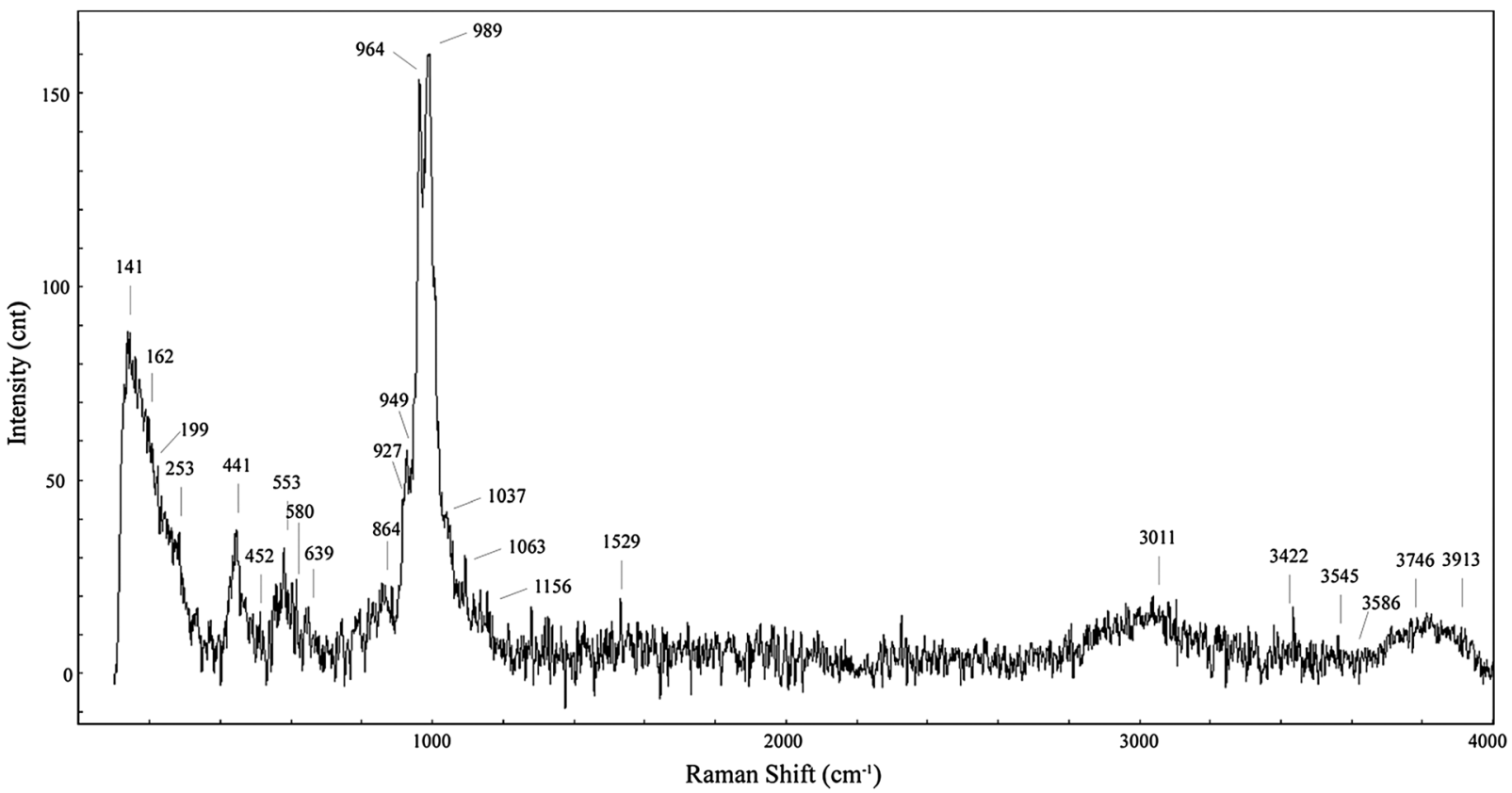

Fig. 2. Raman spectrum of fluorcarmoite-(BaNa) over the $100-4000 \mathrm{~cm}^{-1}$ range. 
Table 2. X-ray powder diffraction data for fluorcarmoite-(BaNa).*

\begin{tabular}{rrrllrr}
\hline$h$ & $k$ & \multicolumn{1}{c}{$l$} & $d_{\text {obs }}(\AA)$ & $d_{\text {calc }}(\AA)$ & \multicolumn{1}{c}{$I_{\text {obs }}$} & \multicolumn{1}{c}{$I_{\text {calc }}$} \\
\hline 1 & 1 & -4 & 5.182 & 5.188 & 11.2 & 6.3 \\
$\mathbf{0}$ & $\mathbf{2}$ & $\mathbf{0}$ & $\mathbf{4 . 9 5 9}$ & $\mathbf{4 . 9 7 4}$ & $\mathbf{2 4 . 8}$ & $\mathbf{2 6 . 1}$ \\
3 & 1 & -2 & 4.733 & 4.731 & 12.9 & 7.3 \\
0 & 2 & 2 & 4.570 & 4.582 & 23.8 & 15.6 \\
$\mathbf{1}$ & $\mathbf{1}$ & $\mathbf{4}$ & $\mathbf{4 . 5 2 4}$ & $\mathbf{4 . 5 2 6}$ & $\mathbf{1 9 . 9}$ & $\mathbf{2 5 . 1}$ \\
2 & 2 & -2 & 4.150 & 4.158 & 21.7 & 22.4 \\
1 & 1 & 6 & 3.374 & 3.374 & 17.0 & 22.8 \\
3 & 1 & 4 & 3.289 & 3.286 & 10.0 & 20.2 \\
$\mathbf{2}$ & $\mathbf{0}$ & $\mathbf{6}$ & $\mathbf{3 . 1 8 8}$ & $\mathbf{3 . 1 8 6}$ & $\mathbf{2 7 . 5}$ & $\mathbf{4 0 . 3}$ \\
2 & 2 & -6 & 3.097 & 3.102 & 19.6 & 12.3 \\
$\mathbf{4}$ & $\mathbf{2}$ & $-\mathbf{4}$ & $\mathbf{3 . 0 1 2}$ & $\mathbf{3 . 0 1 3}$ & $\mathbf{1 0 0 . 0}$ & $\mathbf{1 0 0 . 0}$ \\
3 & 3 & -2 & 2.818 & 2.823 & 28.4 & 20.0 \\
3 & 1 & -8 & 2.808 & 2.809 & 17.2 & 16.9 \\
3 & 3 & 0 & 2.801 & 2.806 & 12.7 & 11.9 \\
1 & 3 & 4 & 2.772 & 2.777 & 9.9 & 9.4 \\
4 & 0 & -8 & 2.742 & 2.742 & 19.8 & 20.1 \\
$\mathbf{6}$ & $\mathbf{0}$ & $-\mathbf{2}$ & $\mathbf{2 . 7 3 5}$ & $\mathbf{2 . 7 3 0}$ & $\mathbf{3 2 . 1}$ & $\mathbf{2 7 . 3}$ \\
$\mathbf{2}$ & $\mathbf{2}$ & $\mathbf{6}$ & $\mathbf{2 . 6 8 2}$ & $\mathbf{2 . 6 8 3}$ & $\mathbf{3 9 . 2}$ & $\mathbf{4 0 . 3}$ \\
1 & 3 & -6 & 2.567 & 2.572 & 11.0 & 13.8 \\
0 & 2 & 8 & 2.530 & 2.533 & 9.2 & 16.4 \\
$\mathbf{4}$ & $\mathbf{2}$ & $\mathbf{4}$ & $\mathbf{2 . 5 2 6}$ & $\mathbf{2 . 5 2 5}$ & $\mathbf{2 4 . 9}$ & $\mathbf{2 6 . 5}$ \\
0 & 4 & 0 & 2.480 & 2.487 & 9.9 & 19.5 \\
7 & 1 & -6 & 2.182 & 2.180 & 11.8 & 12.6 \\
6 & 4 & -2 & 1.837 & 1.839 & 7.0 & 5.5 \\
\hline
\end{tabular}

*Only reflections with $I_{\text {rel }}>7 \sigma\left(I_{\text {rel }}\right)$ are listed.

The seven strongest reflections are reported in bold.

with a CCD area detector at CrisDi (Interdepartmental Centre for the Research and Development of Crystallography, Torino, Italy) with graphite-monochromatized MoKa radiation. The unit-cell parameters refined from the powder data with the software GSAS (Larson \& Von Dreele, 1994) are: $a=16.426(9), b=9.920(8), c=24.43(3) \AA, \beta=105.65$ $(11)^{\circ}, V=3832(6) \AA^{3}, Z=4$. Fluorcarmoite-(BaNa) is monoclinic, space group $C c$. Observed $d$-spacings and diffraction intensities for $\mathrm{MoK} \alpha$ radiation are compared with those calculated from the structure model using PLATON v-140513 (Spek, 2009) and are reported in Table 2.

Single-crystal X-ray diffraction data were collected on a crystal of $0.200 \times 0.133 \times 0.110 \mathrm{~mm}$ using an Oxford Xcalibur Gemini Ultra diffractometer equipped with a Ruby CCD area detector at $\mathrm{CrisDi}$ with graphitemonochromatised $\mathrm{MoK} \alpha$ radiation $(\lambda=0.71073 \AA)$. No crystal twinning was observed. Crystal data and experimental details are reported in Table 3.

The intensities of 48640 reflections with $-24 \leq h \leq 23$, $-15 \leq k \leq 14,-36 \leq l \leq 37$ were collected to $65.5^{\circ} 2 \theta$ using a $1^{\circ}$ frame and an integration time of $42 \mathrm{~s}$. Data were integrated and corrected for Lorentz and polarization background effects using the package CrysAlisPro (Agilent Technologies, Version 1.171.36.28, release 01-02-2013 CrysAlis171). Data were corrected for empirical absorption using spherical harmonics, implemented in the SCALE3 ABSPACK scaling algorithm in CrysAlisPro. Refinement of the unit-cell parameters was based on 21512 measured reflections with $I>10 \sigma(I)$.

At room temperature, the unit-cell parameters are: $a=16.4013(3), \quad b=9.9487(1), c=24.4536(8) \AA$
Table 3. Crystal data and summary of parameters describing data collection and refinement for fluorcarmoite-(BaNa).

\begin{tabular}{|c|c|}
\hline Crystal system & Monoclinic \\
\hline Space group & $C c$ \\
\hline \multicolumn{2}{|l|}{ Unit-cell dimensions } \\
\hline$a(\AA)$ & 16.4013 \\
\hline$b(\AA)$ & $9.9487(1)$ \\
\hline$c(\AA)$ & $24.4536(8)$ \\
\hline$\beta\left({ }^{\circ}\right)$ & $105.725(2)$ \\
\hline$V\left(\AA^{3}\right)$ & $3840.80(15)$ \\
\hline$Z$ & 4 \\
\hline$F(000)$ & 3616 \\
\hline$D_{\text {calc }}\left(\mathrm{g} \mathrm{cm}^{-3}\right)$ & 3.394 \\
\hline Crystal size (mm) & $0.200 \times 0.133 \times 0.110$ \\
\hline Radiation type & $\operatorname{MoK\alpha }(0.71073 \AA)$ \\
\hline$\theta$-range for data collection $\left(^{\circ}\right)$ & $3.2-32.7$ \\
\hline$R_{\text {int }}(\%)$ & 4.1 \\
\hline Reflections collected & 48778 \\
\hline Independent reflections & 13232 \\
\hline$F_{\mathrm{o}}>4 \sigma|F|$ & 11511 \\
\hline Refinement method & Least-squares, full matrix \\
\hline No. of refined parameters & 847 \\
\hline Final $R_{\text {obs }}(\%)$ all data & 4.17 \\
\hline$R_{1}(\%) F_{\mathrm{o}}>4 \sigma|F|$ & 3.42 \\
\hline$w R_{2}(\%) F_{\mathrm{o}}>4 \sigma|F|$ & 8.77 \\
\hline Highest peak/deepest hole $\left(\mathrm{e}^{-} \AA^{-3}\right)$ & $1.32 /-1.02$ \\
\hline Goodness of fit on $F^{2}$ & 1.040 \\
\hline
\end{tabular}

$\beta=105.725(2)^{\circ}, V=3840.80(15) \AA^{3}, Z=4$, space group $C c$ and $Z=4$. The $a: b: c$ ratio is $1.6486: 1: 2.4580$. The structure was refined starting from the atom coordinates of arrojadite-(KNa) (Cámara et al., 2006) using the SHELX set of programs (Sheldrick, 2008). Structure refinement converged to $R_{1}=0.0342$ for 11511 reflections with $F_{\mathrm{o}}>4 \sigma|F|$ and 0.0417 for all 13232 data. Table 4 reports atomic coordinates. Table S1 with anisotropic-displacement parameters is deposited and available as Supplementary Material linked to this article at https://pubs.geoscienceworld.org/eurjmin. Tables 5-7 report selected bond distances, geometrical parameters and bond valence for fluorcarmoite-(BaNa). Site scattering values and site occupancies are reported in Table 8. The CIF and structure factor list are available as part of the Supplementary Material.

\section{Results}

\subsection{Raman spectroscopy}

The Raman spectrum of fluorcarmoite-(BaNa) from 100 to $4000 \mathrm{~cm}^{-1}$ is reported in Fig. 2. The spectral region between 100 and $700 \mathrm{~cm}^{-1}$ includes the phosphate bending modes $\left(\mathrm{PO}_{4}\right.$ and $\mathrm{PO}_{3}(\mathrm{OH})$ bending vibrations). Quite intense bands are found at 141,162, 199 and $253 \mathrm{~cm}^{-1}$ and these bands may be simply described as lattice vibrations of phosphate groups. A series of broad bands are observed at 441, 452, $553,580,639 \mathrm{~cm}^{-1}$ and these bands are attributed to motions of cations at the $M$ sites.

The Raman spectrum, in the region of $700-1400 \mathrm{~cm}^{-1}$, shows a number of overlapping bands. Intense Raman bands 
Table 4. Atoms, site occupancy (cation sites)/bond valence (B.V., anion sites, valence units, v.u.), fractional atom coordinates ( $\mathrm{A})$, and equivalent isotropic displacement parameters $\left(\AA^{2}\right)$ for fluorcarmoite-(BaNa).

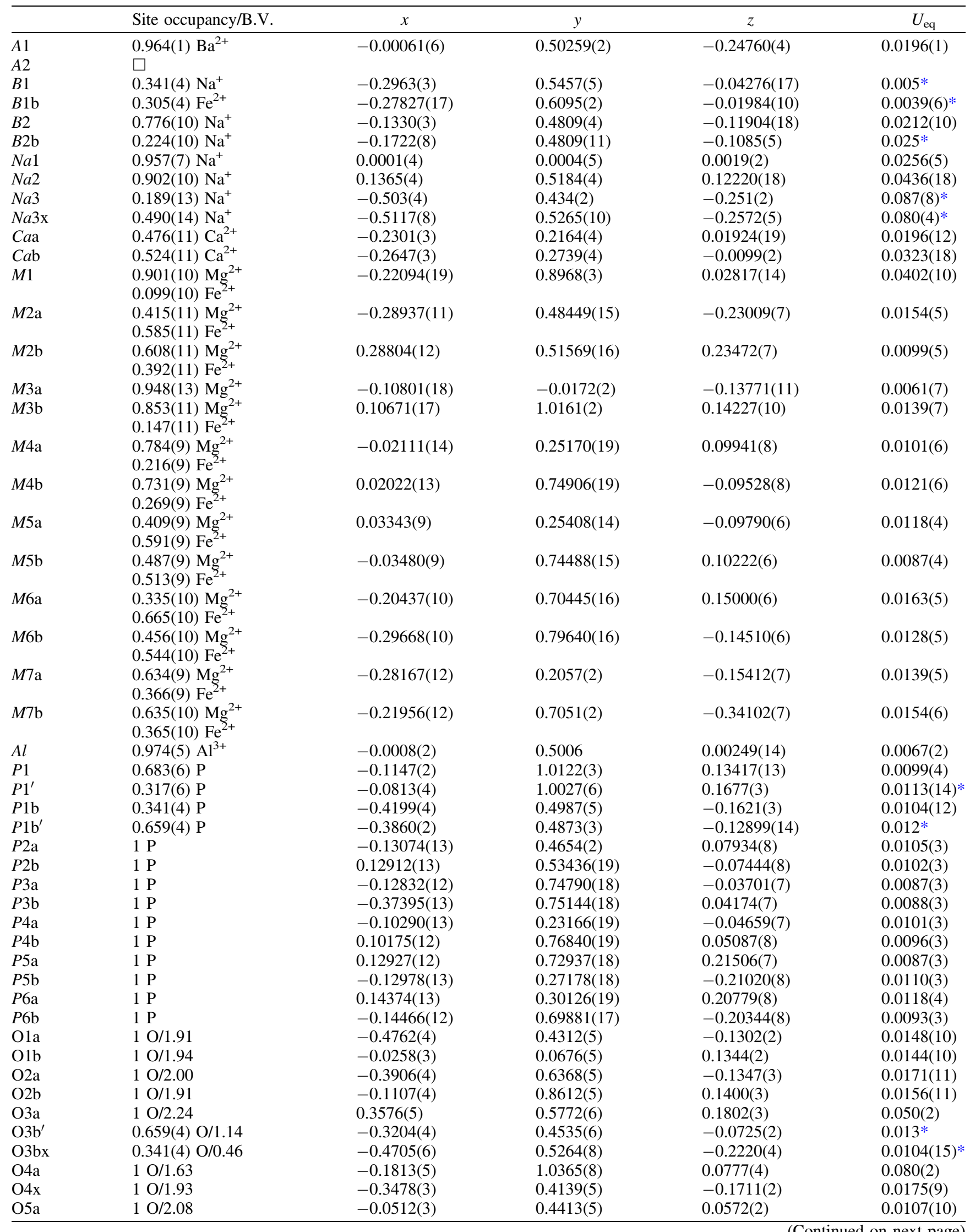


Table 4. (Continued)

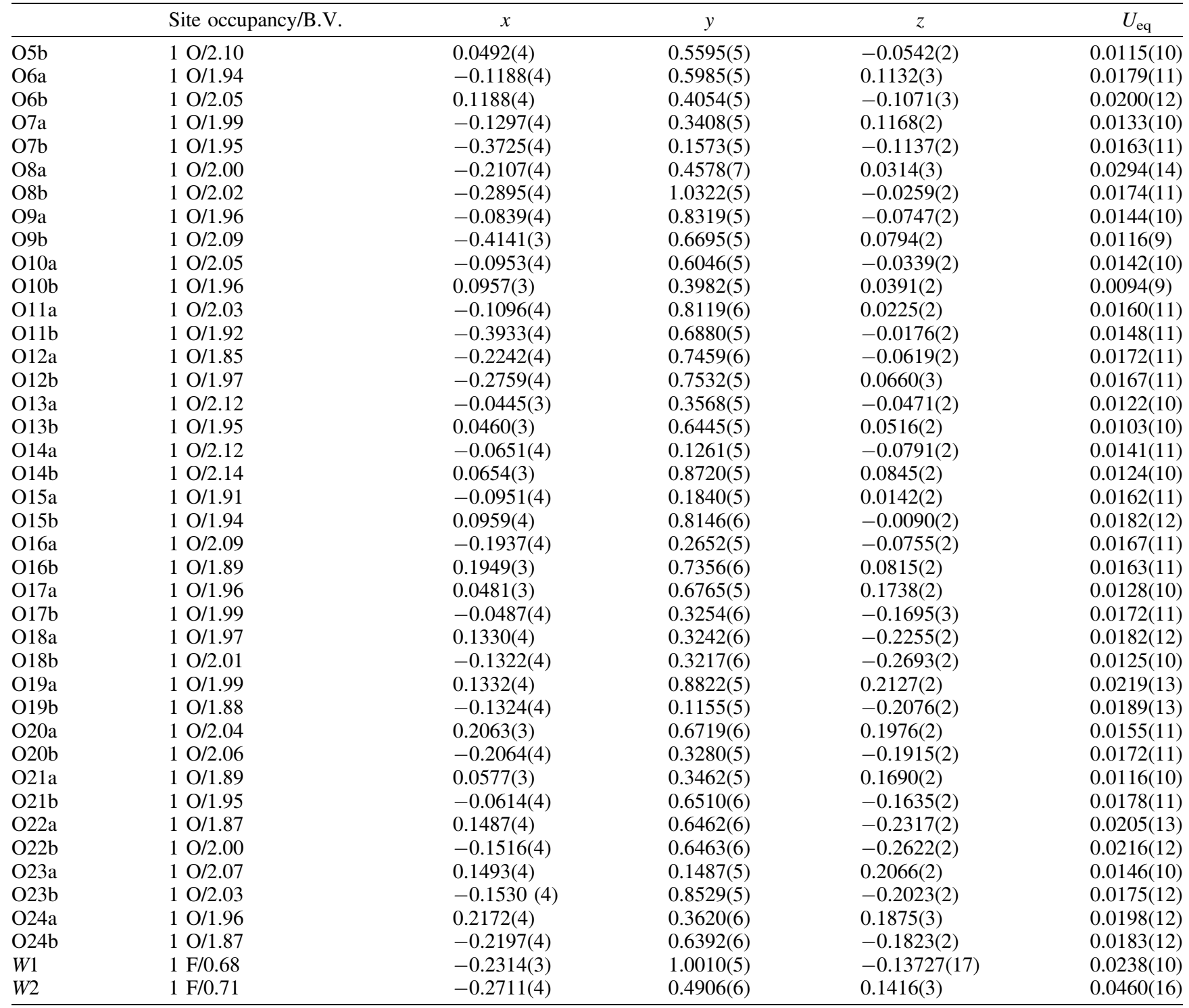

*The temperature factor has the form $\exp (-T)$ where $T=8\left(\pi^{2}\right) U(\sin (\theta) / \lambda)^{2}$ for isotropic atoms.

are observed at 989 and $964 \mathrm{~cm}^{-1}$ with shoulder bands at 949, 927 and $864 \mathrm{~cm}^{-1}$. These bands are assigned to the $\mathrm{PO}_{4} v_{1}$ symmetric stretching modes. The Raman band at $989 \mathrm{~cm}^{-1}$ is attributed to the stretching vibrations of $\mathrm{PO}_{3}(\mathrm{OH})$ groups. Multiple bands are observed depending upon to which cation the phosphate is bonding. Raman shoulder bands are also observed at 1037, 1063 and $1156 \mathrm{~cm}^{-1}$ and these are assigned to the $\mathrm{PO}_{4} v_{3}$ antisymmetric stretching modes (Casciani \& Condrate, 1980; Frost et al., 2013).

In the region of $1800-4000 \mathrm{~cm}^{-1}$ : broad bands and weak shoulders are observed. Band component analysis enables resolution with bands at 3011, 3422, 3545, 3586, 3746 and $3913 \mathrm{~cm}^{-1}$ that might be assigned to $\mathrm{OH}$ stretching modes. However, the stretching modes described by Cámara et al. (2006), Frost et al. (2013) and Della Ventura et al. (2014) are a doublet centred at ca. 3526 and $3554 \mathrm{~cm}^{-1}$.
Weak components at $3100-3200 \mathrm{~cm}^{-1}$ are reported by Frost et al. (2013) and by Della Ventura et al. (2014) and can be interpreted as due to the $\mathrm{O} 3 \mathrm{x}-\mathrm{H} 3 \mathrm{x}$ bonding (mistakenly reported by Della Ventura et al. (2014) as $\mathrm{O} 25-\mathrm{H} 3$, as $\mathrm{O} 25 a, b=\mathrm{W} 1,2$ is not involved in the $\mathrm{PO}_{3} \mathrm{OH}$ group). The presence of significant scattering at the $\mathrm{Na3}, 3 \mathrm{x}$ sites implies that the intensity of that vibration must be weak. It is worth noting that Della Ventura et al. (2014) reported the presence of $\mathrm{NH}_{4}{ }^{+}$in arrojadite-(KNa) from Rapid Creek (Yukon) by means of WDS microprobe analysis and FTIR, which would show bands related to $v_{3}$ antisymmetric stretching modes at $c a .3090 \mathrm{~cm}^{-1}$. Additional bending $v_{4}$ modes at $1400 \mathrm{~cm}^{-1}$ are then expected (found by Della Ventura et al., 2014 at $c a .1450 \mathrm{~cm}^{-1}$ ). The presence of a weak band at $1529 \mathrm{~cm}^{-1}$ does not support the presence of $\mathrm{NH}_{4}{ }^{+}$in fluorcarmoite-(BaNa) that could account for the "excess" scattering at the Na3,3x sites (see below). 
Table 5. The phosphate groups. Main interatomic distances $(\AA)$, geometrical parameters and bond valence values ${ }^{\mathrm{a}}$ (v.u.) for fluorcarmoite(BaNa).

\begin{tabular}{|c|c|c|c|c|c|c|c|c|}
\hline$P 1-\mathrm{O} 3 \mathrm{a}$ & $1.474(7)$ & 0.99 & $P 2 \mathrm{~b}-\mathrm{O} 6 \mathrm{~b}$ & $1.497(6)$ & 1.37 & $P 5 \mathrm{a}-019 \mathrm{a}$ & $1.524(6)$ & 1.28 \\
\hline$-\mathrm{O} 2 \mathrm{~b}$ & $1.509(6)$ & 0.91 & $-\mathrm{O} 8 \mathrm{~b}$ & $1.528(6)$ & 1.27 & $-017 \mathrm{a}$ & $1.530(5)$ & 1.27 \\
\hline$-04 a$ & $1.529(8)$ & 0.86 & $-\mathrm{O} 5 \mathrm{~b}$ & $1.542(6)$ & 1.23 & $-018 \mathrm{a}$ & $1.533(6)$ & 1.26 \\
\hline$-01 b$ & $1.556(6)$ & 0.81 & $-07 b$ & $1.551(5)$ & 1.20 & $-020 \mathrm{a}$ & $1.550(5)$ & 1.20 \\
\hline$\langle P 1-\mathrm{O}\rangle$ & 1.517 & 3.57 & $\langle P 2 \mathrm{~b}-\mathrm{O}\rangle$ & 1.530 & 5.08 & $<P 5 \mathrm{a}-\mathrm{O}\rangle$ & 1.534 & 5.01 \\
\hline$V^{\mathrm{b}}\left(\AA^{3}\right)$ & 1.78 & 1.78 & & $V\left(\AA^{3}\right)$ & 1.83 & & $V\left(\AA^{3}\right)$ & 1.85 \\
\hline$P 1^{\prime *-O} 3 \mathrm{a}$ & $1.346(9)$ & 0.64 & $P 3 a-O 10 a$ & $1.520(5)$ & 1.30 & $P 5 \mathrm{~b}-\mathrm{O} 18 \mathrm{~b}$ & $1.520(5)$ & 1.30 \\
\hline$-01 b$ & $1.520(8)$ & 0.42 & $-012 a$ & $1.525(6)$ & 1.28 & $-017 b$ & $1.526(6)$ & 1.28 \\
\hline$-\mathrm{O} 2 \mathrm{~b}$ & $1.580(8)$ & 0.36 & $-011 \mathrm{a}$ & $1.540(5)$ & 1.23 & $-\mathrm{O} 20 \mathrm{~b}$ & $1.553(6)$ & 1.19 \\
\hline \multirow[t]{2}{*}{$\left.<P 1^{\prime}-\mathrm{O}\right\rangle$} & 1.482 & 1.41 & $-09 a$ & $1.562(6)$ & 1.17 & $-019 b$ & $1.557(5)$ & 1.18 \\
\hline & & & $<P 3 \mathrm{a}-\mathrm{O}>$ & 1.537 & 4.98 & $<P 5 \mathrm{~b}-\mathrm{O}\rangle$ & 1.539 & 4.95 \\
\hline$P 1 \mathrm{~b}-\mathrm{O} 3 \mathrm{bx}$ & $1.502(11)$ & 0.46 & $V\left(\AA^{3}\right)$ & 1.86 & & $V\left(\AA^{3}\right)$ & 1.87 & \\
\hline$-01 \mathrm{a}$ & $1.517(8)$ & 0.44 & & & & & & \\
\hline$-04 x$ & $1.517(8)$ & 0.44 & $P 3 \mathrm{~b}-\mathrm{O} 9 \mathrm{~b}$ & $1.509(6)$ & 1.33 & $P 6 \mathrm{a}-\mathrm{O} 23 \mathrm{a}$ & $1.522(5)$ & 1.29 \\
\hline$-\mathrm{O} 2 \mathrm{a}$ & $1.547(7)$ & 0.41 & $-011 b$ & $1.534(6)$ & 1.25 & $-021 \mathrm{a}$ & $1.538(5)$ & 1.24 \\
\hline$<P 1 \mathrm{~b}-\mathrm{O}>$ & 1.520 & 1.76 & $-\mathrm{O} 10 \mathrm{~b}$ & $1.538(5)$ & 1.24 & $-\mathrm{O} 24 \mathrm{a}$ & $1.546(7)$ & 1.22 \\
\hline \multirow[t]{2}{*}{$V\left(\AA^{3}\right)$} & 1.79 & & $-012 b$ & $1.557(6)$ & 1.18 & $-\mathrm{O} 22 \mathrm{a}$ & $1.551(5)$ & 1.20 \\
\hline & & & $<P 3 \mathrm{~b}-\mathrm{O}\rangle$ & 1.534 & 5.01 & $<P 6 \mathrm{a}-\mathrm{O}>$ & 1.539 & 4.95 \\
\hline$P 1 \mathrm{~b}^{\prime}-\mathrm{O} 2 \mathrm{a}$ & $1.495(6)$ & 0.91 & $V\left(\AA^{3}\right)$ & 1.85 & & $V\left(\AA^{3}\right)$ & 1.87 & \\
\hline$-04 x$ & $1.527(6)$ & 0.84 & & & & & & \\
\hline$-\mathrm{O} 3 \mathrm{~b}^{\prime}$ & $1.541(7)$ & 0.81 & $P 4 \mathrm{a}-\mathrm{O} 16 \mathrm{a}$ & $1.503(6)$ & 1.35 & $P 6 \mathrm{~b}-\mathrm{O} 22 \mathrm{~b}$ & $1.503(69$ & 1.35 \\
\hline$-01 \mathrm{a}$ & $1.574(7)$ & 0.75 & $-015 a$ & $1.533(6)$ & 1.26 & $-021 b$ & $1.524(6)$ & 1.28 \\
\hline$\left.<P 1 b^{\prime}-\mathrm{O}\right\rangle$ & 1.534 & 3.31 & $-014 a$ & $1.544(5)$ & 1.22 & $-\mathrm{O} 23 \mathrm{~b}$ & $1.540(5)$ & 1.23 \\
\hline \multirow[t]{2}{*}{$V\left(\AA^{3}\right)$} & 1.84 & & $-013 a$ & $1.573(5)$ & 1.14 & $-\mathrm{O} 24 \mathrm{~b}$ & $1.574(6)$ & 1.13 \\
\hline & & & $<P 4 \mathrm{a}-\mathrm{O}>$ & 1.538 & 4.97 & $<P 6 \mathrm{~b}-\mathrm{O}>$ & 1.535 & 5.01 \\
\hline$P 2 \mathrm{a}-08 \mathrm{a}$ & $1.506(6)$ & 1.34 & $V\left(\AA^{3}\right)$ & 1.86 & & $V\left(\AA^{3}\right)$ & 1.85 & \\
\hline$-07 a$ & $1.538(5)$ & 1.24 & & & & & & \\
\hline$-06 a$ & $1.546(5)$ & 1.22 & $P 4 \mathrm{~b}-\mathrm{O} 15 \mathrm{~b}$ & $1.512(6)$ & 1.32 & & & \\
\hline$-05 a$ & $1.561(5)$ & 1.17 & $-\mathrm{O} 14 \mathrm{~b}$ & $1.536(6)$ & 1.25 & & & \\
\hline \multirow{4}{*}{$\begin{array}{c}V\left(\AA^{3}\right) \\
\end{array}$} & 1.538 & 4.97 & $-\mathrm{O} 13 \mathrm{~b}$ & $1.538(6)$ & 1.24 & & & \\
\hline & 1.851 & & $-016 b$ & $1.543(6)$ & 1.23 & & & \\
\hline & & & $<P 4 \mathrm{~b}-\mathrm{O}>$ & 1.532 & 5.04 & & & \\
\hline & & & $V\left(\AA^{3}\right)$ & 1.84 & & & & \\
\hline
\end{tabular}

${ }^{\mathrm{a} B o n d-v a l e n c e ~ p a r a m e t e r s ~ f r o m ~ G a g n e ́ ~ \& ~ H a w t h o r n e ~(2015) ~ f o r ~ b o n d ~ w i t h ~} \mathrm{O}^{=}$and from Brown (1981) for bonds with $\mathrm{F}^{-}$.

${ }^{\mathrm{b}}$ The fourth oxygen could not be identified in the Fourier-difference map and was not added to the model; bond valence at split sites $P 1$ and $P 1^{\prime}$ and $P 1 \mathrm{~b}$ and $P 1 \mathrm{~b}^{\prime}$ correspond to the partial occupancies at these sites.

$* V=$ polyhedral volume.

\subsection{Description of the structure}

The crystal structure of fluorcarmoite-(Ba,Na) is topologically identical to the structure of arrojadite-(KNa): four-, five- and six coordinated cations are linked by $\left(\mathrm{PO}_{4}\right)$ groups and $\mathrm{Al}$ octahedra sharing apices, except for $M 4 \mathrm{a}, \mathrm{b}$ and $M 5 \mathrm{a}$, $\mathrm{b}$ that share an edge with $P 2 \mathrm{a}, \mathrm{b}$ and $P 4 \mathrm{a}, \mathrm{b}$, respectively - in fact these cation polyhedra show the highest angle-variance values $\left(\sigma^{2}\right.$, Tables 5 and 6$)$ along with $P 1$ sites. Interestingly, site-scattering refinement (Hawthorne et al., 1995) shows the highest scattering for the M5a,b and M6a,b sites, indicating that $\mathrm{Fe}^{2+}$ orders preferentially in these sites (Table 4).

From the point of view of the Structure Hierarchy Hypothesis (Hawthorne, 1983, 1994), "structures may be ordered hierarchically according to the polymerization of coordination polyhedra of higher bond valence". Therefore, higher bond-valence polyhedra polymerize to form homo- or heteropolyhedral clusters; these may be considered as the fundamental building block (FBB) of the structure. The FBB is repeated (often polymerized) by symmetry to form the structural unit, a complex (usually anionic) polyhedral array (not necessarily connected). In the case of arrojadite minerals, we can identify the FBB as the complex polyanion $M_{12} \mathrm{O}_{17}(\mathrm{OH}, \mathrm{F})_{6}\left[\mathrm{PO}_{4}\right]_{10}^{6-}$ (Fig. 3a). It is composed of two elements that repeat twice in the FBB: a folded strip of four edge-sharing octahedra and one edge-sharing $\mathrm{PO}_{4}$ group and a strip of two edge-sharing octahedra plus an edge sharing $\mathrm{PO}_{4}$ group (Fig. 3b). Furthermore, six $\mathrm{PO}_{4}$ group link the strip by sharing their vertices. The $M_{12} \mathrm{O}_{17}(\mathrm{OH}, \mathrm{F})_{6}\left[\mathrm{PO}_{4}\right]_{10}^{6-}$ unit repeats along [010] by sharing the $(\mathrm{OH}, \mathrm{F})$ anions with the adjacent units, forming a column of the form $M_{12} \mathrm{O}_{17}(\mathrm{OH}, \mathrm{F})_{6}\left[\mathrm{PO}_{4}\right]_{10}^{6-}$. Within the (010) plane, these columns link by sharing $(\mathrm{OH}, \mathrm{F})$ anions and vertices of $\mathrm{PO}_{4}$ tetrahedra, plus other $\left(\mathrm{PO}_{4}\right)$ and $\left(\mathrm{AlO}_{6}\right)$ groups, as well as the $M 1$ tetrahedron. Monovalent and divalent alkaline-earth cations occur in the interstitial voids as well as within the columns. There are four $M_{12} \mathrm{O}_{17}(\mathrm{OH}, \mathrm{F})_{6}\left[\mathrm{PO}_{4}\right]_{10}^{6-}$ per unit cell.

The structure (Fig. 4) shows disorder at alkali sites and $P 1$ sites, which have been modelled as split sites, following Cámara et al. (2006). The refinement converged to a 1/3:2/3 population, not compatible with a missing centre of 
Table 6. The $A l$ and $M$ sites. Main interatomic distances $(\AA)$, geometrical parameters and bond valence values ${ }^{\text {a }}$ (v.u.) for fluorcarmoite(BaNa).

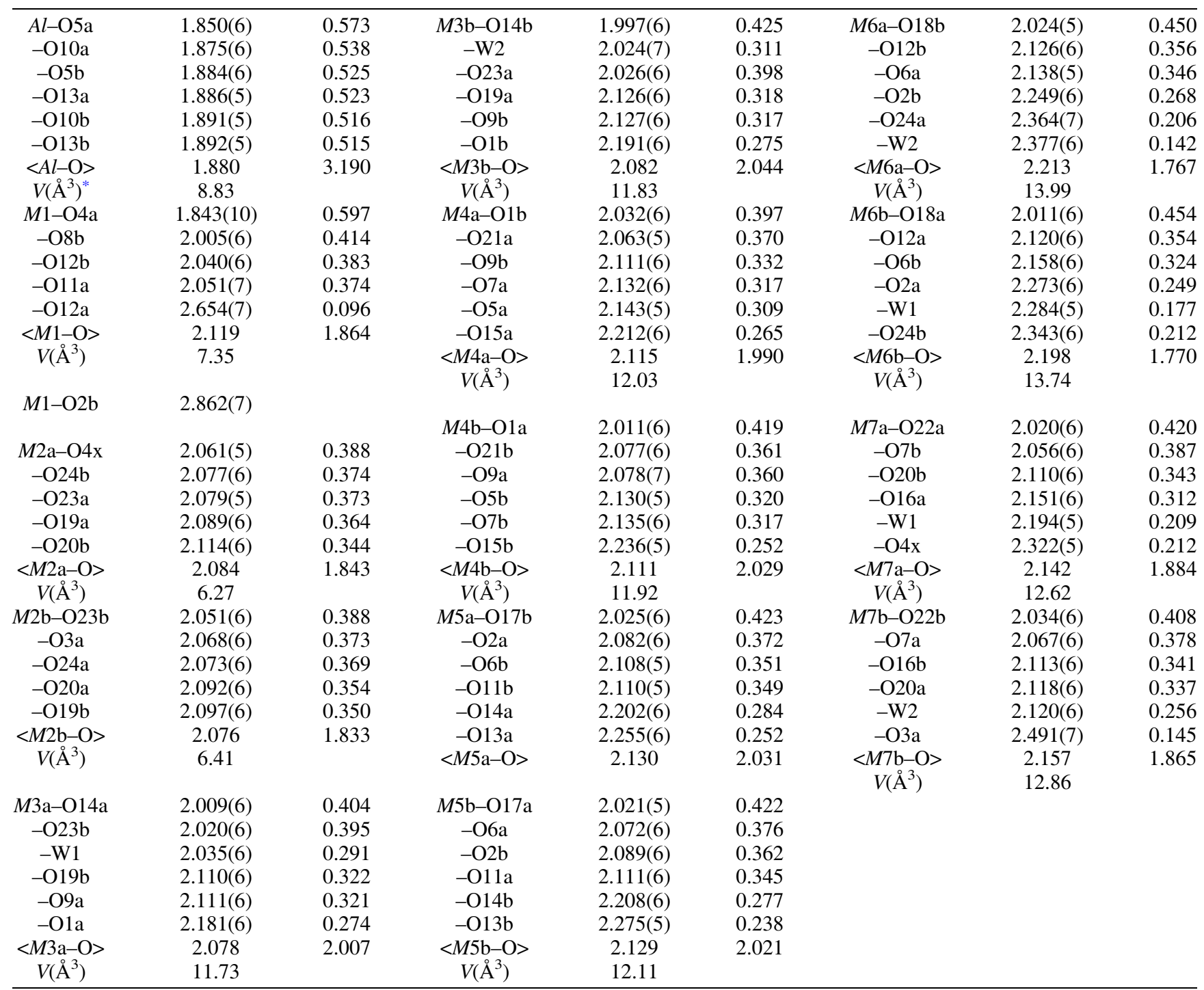

${ }^{a}$ Bond-valence parameters from Gagné \& Hawthorne (2015) for bond with $\mathrm{O}^{=}$and from Brown (1981) for bonds with $\mathrm{F}^{-}$.

$* V=$ polyhedral volume.

symmetry as proposed by other authors (Kallfaß et al., 2010; Vignola et al., 2016). It seems therefore that the apparent presence of a centre of symmetry in some other localities is the result of local disorder due to high-temperature crystal growth. The shape of the electron density at some anion sites is oblate and represents local disorder associated with complex cation order. In particular, disorder is present at $N a 3$ and Na3x, but chemical composition implies that the overall cation occupancy of the $\mathrm{Na3}$ cavity is $<0.5$ apfu, and thus the third modifier is not required for naming. Consequently, the occupancy of $\mathrm{H3x}$ is reduced and explains - along with the fluorine content - the weak bands observed in the $\mathrm{OH}$-stretching region of the Raman spectrum.

Using the chemical analysis and the observed site scattering, it is also possible to assign ions to specific sites
(Table 8). The agreement is very good. The incident bond-valence in Table 4 validates the model. Anions at the $W 1$ and $W 2$ sites show incident bond-valence $<1$ valence units (v.u.) characteristic of $\mathrm{F}^{-}$ions or $(\mathrm{OH})$ groups. The other anion sites are $\mathrm{O}^{3} \mathrm{~b}^{\prime}$ and $\mathrm{O} 3 \mathrm{bx}$, which are two split sites related to the disorder of the $P 1$ sites and to the partial occupancy of the $\mathrm{Na3}$ site by $\mathrm{Na}$ and $\mathrm{K}$ (or $\mathrm{H}$ in case of vacancy at the $\mathrm{Na3}$ site).

In Table 8 , the ordering of $\mathrm{Fe}^{2+}$ (and $\mathrm{Mn}^{2+}$ ) is evident, with preference for the distorted M2a, M5a,b as well as the more regular but still larger M6a,b sites. In particular, some $\mathrm{Na}$ is disordered over the M6a,b and M7a,b sites, in agreement with the site scattering as well as mean bondlength. $\mathrm{Na}$ can therefore disorder the inter-column sites and the octahedra, exchanging with $\mathrm{Fe}^{2+}$. This exchange is probably related to high-temperature crystallization, in 
Table 7. The alkali sites. Selected interatomic distances $(\AA)$, geometrical parameters and bond valence values ${ }^{\mathrm{a}}$ (v.u.) for fluorcarmoite(BaNa).

\begin{tabular}{|c|c|c|c|c|c|c|c|c|}
\hline$A 1-\mathrm{O} 18 \mathrm{~b}$ & $2.749(6)$ & 0.264 & $B 2 \mathrm{~b}-\mathrm{O} 10 \mathrm{a}$ & $2.278(12)$ & 0.055 & $\mathrm{Na2}-\mathrm{O} 10 \mathrm{~b}$ & $2.296(6)$ & 0.203 \\
\hline$-018 \mathrm{a}$ & $2.758(6)$ & 0.258 & -016a & $2.352(12)$ & 0.046 & $-013 b$ & $2.317(7)$ & 0.193 \\
\hline$-022 \mathrm{a}$ & $2.770(6)$ & 0.251 & $-\mathrm{O} 24 \mathrm{~b}$ & $2.363(12)$ & 0.045 & $-024 a$ & $2.362(7)$ & 0.174 \\
\hline$-\mathrm{O} 22 \mathrm{~b}$ & $2.798(6)$ & 0.234 & $-\mathrm{O} 20 \mathrm{~b}$ & $2.476(12)$ & 0.034 & $-\mathrm{O} 20 \mathrm{a}$ & $2.428(7)$ & 0.148 \\
\hline$-017 b$ & $2.863(6)$ & 0.200 & $-013 a$ & $2.543(13)$ & 0.029 & $-\mathrm{O} 21 \mathrm{a}$ & $2.591(8)$ & 0.101 \\
\hline$-017 \mathrm{a}$ & $2.887(6)$ & 0.188 & $-\mathrm{O} 3 \mathrm{~b}^{\prime}$ & $2.815(15)$ & 0.015 & $-016 b$ & $2.663(8)$ & 0.085 \\
\hline$-\mathrm{O} 21 \mathrm{a}$ & $2.898(5)$ & 0.183 & $-04 x$ & 2.948 (13) & 0.011 & $-017 \mathrm{a}$ & $2.676(8)$ & 0.082 \\
\hline$-\mathrm{O} 21 \mathrm{~b}$ & $2.919(6)$ & 0.174 & $-\mathrm{O} 21 \mathrm{~b}$ & 3.049 (14) & 0.009 & $-05 a$ & $3.152(8)$ & 0.026 \\
\hline$\langle A 1-\mathrm{O}\rangle$ & 2.830 & 1.754 & $\langle B 2 \mathrm{~b}-\mathrm{O}\rangle$ & 2.603 & 0.244 & $<N a 2-\mathrm{O}>$ & 2.561 & 1.013 \\
\hline$V\left(\AA^{3}\right)^{*}$ & 31.59 & & $V\left(\AA^{3}\right)$ & 26.78 & & $V\left(\AA^{3}\right)$ & 25.22 & \\
\hline B1-O8a & $2.154(7)$ & 0.137 & Caa-O16b & $2.210(7)$ & 0.215 & $\mathrm{Na3}-\mathrm{O} 3 \mathrm{a}$ & $2.45(6)$ & 0.054 \\
\hline$-011 b$ & $2.335(7)$ & 0.089 & $-08 b$ & $2.223(7)$ & 0.208 & $-01 b$ & $2.74(5)$ & 0.026 \\
\hline$-012 \mathrm{a}$ & $2.426(7)$ & 0.072 & $-015 a$ & $2.274(7)$ & 0.183 & $-04 x$ & $2.76(6)$ & 0.025 \\
\hline$-\mathrm{O} 2 \mathrm{a}$ & $2.528(7)$ & 0.056 & $-04 a$ & $2.296(9)$ & 0.174 & $-01 \mathrm{a}$ & $2.86(5)$ & 0.019 \\
\hline$-015 b$ & $3.144(7)$ & 0.013 & $-08 \mathrm{a}$ & $2.430(8)$ & 0.125 & $-023 a$ & $3.07(6)$ & 0.011 \\
\hline$\langle B 1-\mathrm{O}\rangle$ & 2.517 & 0.368 & $-016 a$ & $2.590(7)$ & 0.085 & $-\mathrm{O} 23 \mathrm{~b}$ & $3.10(6)$ & 0.011 \\
\hline \multirow[t]{2}{*}{$V\left(\AA^{3}\right)$} & 12.68 & & $-07 a$ & $2.793(7)$ & 0.052 & $-019 b$ & $3.17(5)$ & 0.009 \\
\hline & & & $-015 b$ & $2.917(8)$ & 0.038 & $-019 \mathrm{a}$ & 3.19 (5) & 0.008 \\
\hline$B 1-\mathrm{O}^{\prime} \mathrm{b}^{\prime}$ & $1.170(7)$ & & $\begin{array}{c}<C a \mathrm{a}-\mathrm{O}> \\
V\left(\AA^{3}\right)\end{array}$ & $\begin{array}{l}2.467 \\
25.28\end{array}$ & 1.079 & $\begin{array}{c}<N a 3-\mathrm{O}> \\
V\left(\AA^{3}\right)\end{array}$ & $\begin{array}{c}2.92 \\
29.41\end{array}$ & 0.165 \\
\hline$B 1 \mathrm{~b}-\mathrm{O} 3 \mathrm{~b}^{\prime}$ & $2.014(6)$ & 0.149 & $\mathrm{Cab}-\mathrm{O} 8 \mathrm{a}$ & $2.160(8)$ & 0.264 & $\mathrm{Na} 3 \mathrm{x}-\mathrm{O} 3 \mathrm{a}$ & $2.495(13)$ & 0.033 \\
\hline$-012 \mathrm{a}$ & $2.045(6)$ & 0.139 & $-016 a$ & $2.225(7)$ & 0.225 & $-\mathrm{O} 19 \mathrm{~b}$ & $2.735(15)$ & 0.018 \\
\hline$-011 b$ & 2.057 (6) & 0.135 & $-\mathrm{O} 15 \mathrm{~b}$ & $2.327(8)$ & 0.175 & $-\mathrm{O} 1 \mathrm{~b}$ & $2.760(13)$ & 0.017 \\
\hline$-08 \mathrm{a}$ & $2.078(7)$ & 0.129 & $-\mathrm{O} 3 \mathrm{~b}^{\prime}$ & $2.369(8)$ & 0.158 & $-019 a$ & $2.821(15)$ & 0.015 \\
\hline$-012 b$ & $2.533(6)$ & 0.047 & $-\mathrm{O} 8 \mathrm{~b}$ & $2.452(7)$ & 0.129 & $-\mathrm{O} 2 \mathrm{~b}$ & $2.827(13)$ & 0.015 \\
\hline$<B 1 \mathrm{~b}-\mathrm{O}>$ & 2.146 & 0.598 & $-016 b$ & $2.526(7)$ & 0.108 & $-04 x$ & $3.138(13)$ & 0.007 \\
\hline \multirow[t]{4}{*}{$V\left(\AA^{3}\right)$} & 7.74 & & $-015 a$ & $2.829(8)$ & 0.051 & $-01 \mathrm{a}$ & $3.148(13)$ & 0.007 \\
\hline & & & $-07 b$ & $2.913(7)$ & 0.042 & $<N a 3 x-O>$ & 2.846 & 0.113 \\
\hline & & & $<C a b-\mathrm{O}\rangle$ & 2.475 & 1.153 & $V\left(\AA^{3}\right)$ & 23.61 & \\
\hline & & & $V\left(\AA^{3}\right)$ & 25.32 & & & & \\
\hline B2-O13a & $2.313(7)$ & 0.179 & $\mathrm{Na1}-\mathrm{O} 14 \mathrm{a}$ & $2.342(8)$ & 0.210 & $N a 3 \mathrm{x}-\mathrm{O} 3 \mathrm{bx}$ & $0.939(14)$ & \\
\hline$-010 a$ & $2.352(7)$ & 0.163 & $-014 b$ & $2.385(7)$ & 0.190 & Na3-O3bx & $1.19(4)$ & \\
\hline$-\mathrm{O} 24 \mathrm{~b}$ & $2.388(7)$ & 0.150 & $-015 \mathrm{a}$ & $2.473(8)$ & 0.154 & & & \\
\hline$-\mathrm{O} 20 \mathrm{~b}$ & $2.398(7)$ & 0.146 & $-015 b$ & $2.487(8)$ & 0.149 & & & \\
\hline$-\mathrm{O} 21 \mathrm{~b}$ & $2.473(7)$ & 0.122 & $-09 a$ & $2.611(8)$ & 0.111 & & & \\
\hline$-017 b$ & $2.599(8)$ & 0.091 & $-09 b$ & $2.638(8)$ & 0.104 & & & \\
\hline$-016 a$ & $2.703(7)$ & 0.071 & $-\mathrm{O} 11 \mathrm{~b}$ & $2.686(9)$ & 0.093 & & & \\
\hline$-\mathrm{O} 5 \mathrm{~b}$ & $3.081(7)$ & 0.029 & $-011 \mathrm{a}$ & $2.738(9)$ & 0.082 & & & \\
\hline$<B 2-\mathrm{O}\rangle$ & 2.538 & 0.951 & $<N a 1-\mathrm{O}>$ & 2.545 & 1.091 & & & \\
\hline$V\left(\AA^{3}\right)$ & 24.95 & & $V\left(\AA^{3}\right)$ & 25.09 & & & & \\
\hline
\end{tabular}

${ }^{a}$ Bond-valence parameters from Gagné \& Hawthorne (2015) for bond with $\mathrm{O}^{=}$and from Brown (1981) for bonds with $\mathrm{F}^{-}$.

$* V=$ polyhedral volume; bond valence in split sites ( $B 1$ and $B 1 \mathrm{~b}, B 2$ and $B 2 \mathrm{~b}, C a \mathrm{a}$ and $C a \mathrm{~b}, N a 3$ and $N a 3 \mathrm{x})$ correspond to the partial occupancies at these sites.

agreement with the split model for $P 1$ and some alkali sites. Note that the observed site distribution of $\mathrm{Mg}$ and $\mathrm{Fe}^{2+}\left(\mathrm{Mn}^{2+}\right)$ in fluorocarmoite-(NaBa) (Table 8) agrees closely with the site populations of Cámara et al. (2006) in samples from Rapid Creek and Horrsjöberg, which have lower $\mathrm{Mg}$ (2.69 and 3.61 apfu, respectively).

\section{Related minerals}

Fluorcarmoite-(BaNa), ${ }^{\mathrm{A} 1} \mathrm{Ba}^{\mathrm{A} 2} \square^{\mathrm{B} 1,2} \mathrm{Na}^{\mathrm{Na} 1,2} \mathrm{Na}_{2}{ }^{\mathrm{Na} 3} \square \square^{\mathrm{Ca}} \mathrm{Ca}$ $\left(\mathrm{Mg}, \mathrm{Fe}^{2+}, \mathrm{Mn}^{2+}\right)_{12} \mathrm{Al}\left(\mathrm{PO}_{4}\right)_{11}\left(\mathrm{PO}_{3} \mathrm{OH}\right) \mathrm{F}_{2}$, is a new member of the arrojadite group (Table 9). Provided that the environment is low in $\mathrm{Fe}$ and $\mathrm{Mn}$, it seems possible to find other members of the arrojadite group with the root-name carmoite. The other sample reported in literature with high, but not dominant Mg-content is sample Gentile-154 from Spluga Valley (Lombardy, Italy; Demartin et al., 1996; Chopin et al., 2006), which has up to $5.68 \mathrm{Mg}$ apfu (lower than the 8.12 apfu of $\mathrm{Fe}^{2+}$, the dominant element). The refinement of Demartin et al. (1996) shows Mg ordered preferentially at the $M 1, M 3$ and $M 4$ sites, in agreement with the findings of this study for the Mg-dominant end-member.

Nowadays, the structure of phosphates containing large channels is of interest in Material Sciences because of the possibility to use their analogues as feasible novel alkalimetal ion batteries (Trad et al., 2010). In particular, sulphate analogues of alluaudite have been tested and show promising properties (Marinova et al., 2015). Preliminary tests on materials with the arrojadite topology have been done by Kallfaß et al. (2011), who described it as a novel cathode material which exhibits an excellent cycle behaviour 
Table 8. Site-scattering values* and site occupancies (excluding P sites).

\begin{tabular}{|c|c|c|c|}
\hline Site & Occupancy & eps (calc) & eps (obs) \\
\hline$A 1$ & $\left(\mathrm{Ba}_{0.93} \mathrm{Sr}_{0.05}\right)_{\Sigma 0.98}$ & 54 & $54.0(8)$ \\
\hline$A 2$ & $(\square)$ & & \\
\hline$B 1$ & $\left(\mathrm{Na}_{\mathbf{0 . 4 1}} \mathrm{Fe}_{0.33}^{2+}\right)_{\Sigma 0.74}$ & 13.1 & $11.67(6)$ \\
\hline$N a 1$ & $\mathrm{Na}_{0.98}$ & 10.8 & $10.6(1)$ \\
\hline $\mathrm{Na2}$ & $\mathrm{Na}_{0.85}$ & 9.4 & $9.90(1)$ \\
\hline$N a 3$ & $\left(\mathrm{Na}_{0.22} \mathrm{~K}_{0.15}\right)_{\Sigma 0.37}$ & 5.3 & 7.5(1.4) \\
\hline$A l$ & $\left(\mathrm{Al}_{0.97} \mathrm{Fe}_{0.02}^{3+} \square_{0.01}\right)_{\Sigma 1}$ & 13.1 & $12.7(2)$ \\
\hline$M 1$ & $\left(\mathrm{Mg}_{0.88} \mathrm{Fe}_{0.12}^{2+}\right)_{\Sigma 1}$ & 13.7 & $13.4(1)$ \\
\hline$M 2 \mathrm{a}$ & $\left(\mathrm{Mg}_{0.39} \mathrm{Fe}_{0.61}^{2+}\right)_{\Sigma 1}$ & 20.5 & $20.2(1)$ \\
\hline$M 2 \mathrm{~b}$ & $\left(\mathrm{Mg}_{0.58} \mathrm{Fe}_{0.42}^{2+}\right)_{\Sigma 1}$ & 18.3 & $17.5(1)$ \\
\hline$M 3 \mathrm{a}$ & $\mathrm{Mg}_{1}$ & 12 & $11.4(2)$ \\
\hline M5a & $\left(\mathrm{Mg}_{0.37} \mathrm{Fe}_{0.61}^{2+} \mathrm{Mn}_{0.02}\right)_{\Sigma 1}$ & 20.8 & $20.3(1)$ \\
\hline$M 5 \mathrm{~b}$ & $\left(\mathrm{Mg}_{0.46} \mathrm{Fe}_{0.52}^{2+} \mathrm{Mn}_{0.02}\right)_{\Sigma 1}$ & 19.5 & $19.2(1)$ \\
\hline M6a & $\left(\mathrm{Mg}_{0.18} \mathrm{Fe}_{0.74}^{2+} \mathrm{Mn}_{0.25} \mathrm{Na}_{0.10}\right)_{\Sigma 1}$ & 21.7 & $21.3(1)$ \\
\hline$M 6 b$ & $\left(\mathrm{Mg}_{0.29} \mathrm{Fe}_{0.40}^{2+} \mathrm{Mn}_{0.19} \mathrm{Na}_{0.12}\right)_{\Sigma 1}$ & 20 & $19.6(1)$ \\
\hline$M 7 \mathrm{a}$ & $\left(\mathrm{Mg}_{0.55} \mathrm{Fe}_{0.37}^{2+} \mathrm{Mn}_{0.03} \mathrm{Na}_{0.05}\right)_{\Sigma 1}$ & 17.5 & 17.1(1) \\
\hline \multirow[t]{3}{*}{$M 7 \mathrm{~b}$} & $\left(\mathrm{Mg}_{0.55} \mathrm{Fe}_{0.35}^{2+} \mathrm{Mn}_{0.04} \mathrm{Na}_{0.06}\right)_{\Sigma 1}$ & 17.4 & $17.0(1)$ \\
\hline & & $\Sigma 240.3$ & $\Sigma 234.6$ \\
\hline & & $\sum 362.5$ & $\Sigma 359.3$ \\
\hline
\end{tabular}

*In the sense of Hawthorne et al. (1995), in electrons per site (eps).
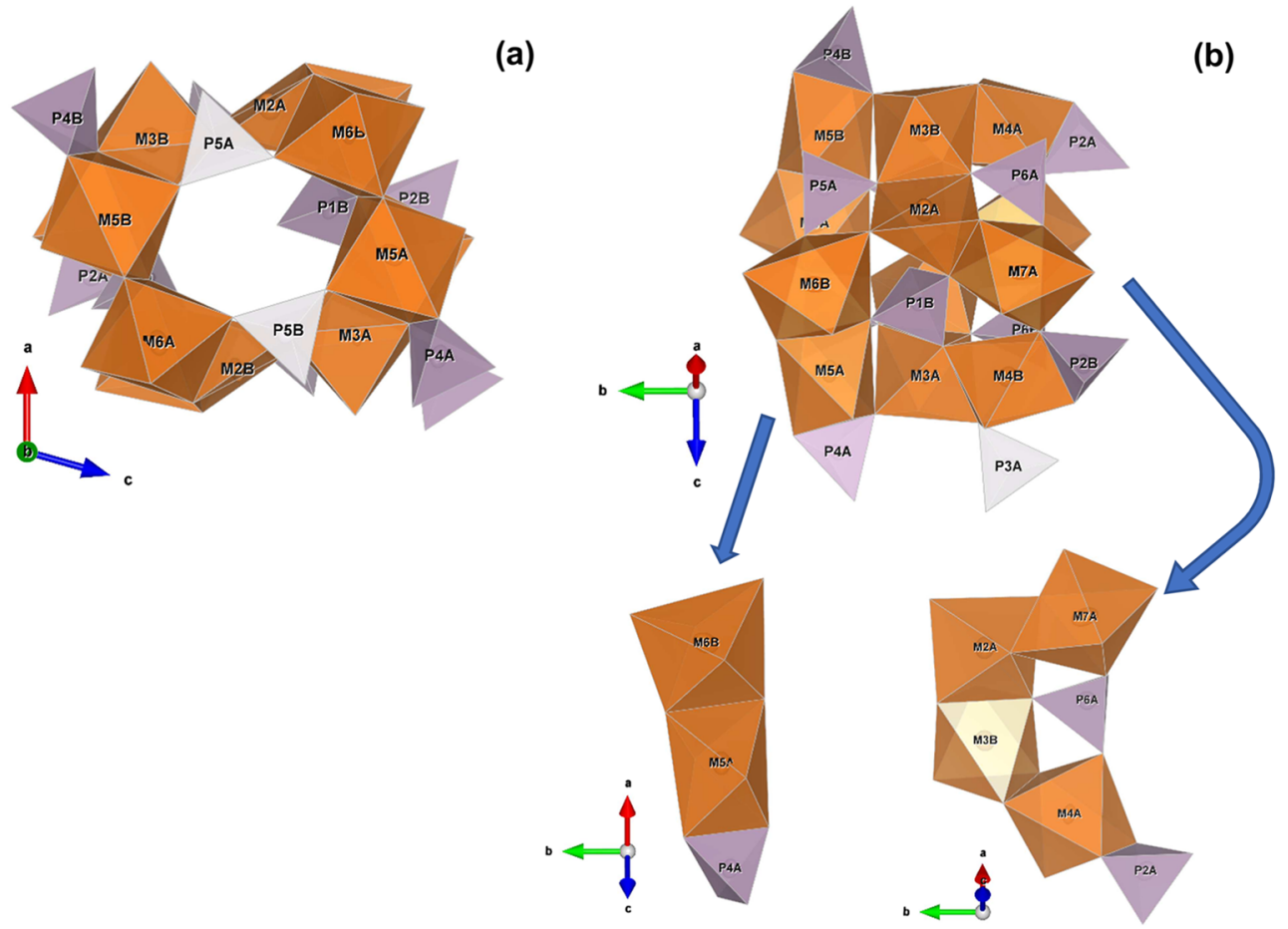

Fig. 3. The $M_{12} \mathrm{O}_{17}(\mathrm{OH}, \mathrm{F})_{6}\left[\mathrm{PO}_{4}\right]_{10}^{6-}$ unit from [010] (a) and onto (100) (b), with details of the two building strips. $M$ sites in orange, $P$ sites in violet. Drawing obtained with VESTA 3 (Momma \& Izumi, 2011). 
Table 9. Arrojadite group. Comparison of three different root-name members of the group.

\begin{tabular}{|c|c|c|c|}
\hline & Fluorcarmoite-(BaNa) & Arrojadite-(KNa) & Dickinsonite-(KMnNa) \\
\hline Reference & (1) & $(2)$ & (2) \\
\hline Ideal formula & $\mathrm{BaNaCaNa}_{2} \mathrm{Mg}_{12} \mathrm{Al}\left(\mathrm{PO}_{4}\right)_{11}$ & $\mathrm{KNa}_{3}\left(\mathrm{CaNa}_{2}\right) \mathrm{Fe}_{13}^{2+} \mathrm{Al}\left(\mathrm{PO}_{4}\right)_{11}$ & $\mathrm{~K}(\mathrm{NaMn}) \mathrm{CaNa}_{3} \mathrm{AlMn}_{13}$ \\
\hline & $\left(\mathrm{PO}_{3} \mathrm{OH}\right) \mathrm{F}_{2}$ & $\left(\mathrm{PO}_{3} \mathrm{OH}\right)(\mathrm{OH})_{2}$ & $\left(\mathrm{PO}_{4}\right)_{12}(\mathrm{OH})_{2}$ \\
\hline Crystal system & Monoclinic & Monoclinic & Monoclinic \\
\hline Space group & $C c$ & $C c$ & Cc \\
\hline$a(\AA)$ & $16.4013(3)$ & $16.5220(11)$ & $16.6900(9)$ \\
\hline$b(\AA)$ & $9.9487(1)$ & $10.0529(7)$ & $10.1013(5)$ \\
\hline$c(\AA)$ & $24.4536(8)$ & $24.6477(16)$ & $24.8752(13)$ \\
\hline$\beta\left(^{\circ}\right)$ & $105.725(2)$ & $106.509(2)$ & $105.616(2)$ \\
\hline$V\left(\AA^{3}\right)$ & $3840.80(15)$ & $3932.2(7)$ & $4038.9(7)$ \\
\hline$Z$ & 4 & 4 & 4 \\
\hline Axial ratios $(\mathbf{a}: \mathbf{b}: \mathbf{c})$ & $1.649: 1: 2.458$ & $1.643: 1: 2.452$ & $1.652: 1: 2.463$ \\
\hline$D_{\text {meas }}\left(\mathrm{g} \mathrm{cm}^{-3}\right)$ & 3.40 & Unknown & Unknown \\
\hline$D_{\text {calc }}\left(\mathrm{g} \mathrm{cm}^{-3}\right)$ & 3.394 & 3.437 & 3.496 \\
\hline Strongest lines in & 3.012(100), 2.682(39), & 3.049(100), 2.691(71) & 3.04(100), 2.717(80) \\
\hline powder pattern: $d_{\text {obs }}(\AA)(I)$ & $\begin{array}{l}2.735(32), 2.818(28), \\
3.188(28), 2.526(25), \\
4.959(25), 4.570(24), \\
4.150(22), 4.5242(20)\end{array}$ & $\begin{array}{c}5.861(29), 2.793(28), 5.026(28), \\
2.798(25), 2.777(24)\end{array}$ & $\begin{array}{c}3.22(60), 2.85(45) \\
5.93(40), 2.770(40), 2.554(35)\end{array}$ \\
\hline Optical character & $\begin{array}{c}\text { Biaxial }(+), n_{\alpha}=1.6240(5), \\
n_{\beta}=1.6255(5), \\
n_{\gamma}=1.6384(5)(589 \mathrm{~nm}), \\
2 V_{\text {meas. }}=35(2)^{\circ}, 2 V_{\text {calc. }}=38^{\circ}\end{array}$ & $\begin{array}{c}\text { Biaxial }(+), n_{\alpha}=1.651(1), \\
n_{\beta}=1.656(1), \\
n_{\gamma}=1.662(10)(589 \mathrm{~nm}), \\
2 V_{\text {meas. }}=87.8(1)^{\circ}, 2 V_{\text {calc. }}=85^{\circ}\end{array}$ & $\begin{array}{c}\text { Biaxial }(+), n_{\alpha}=1.658 \\
n_{\beta}=1.662, n_{\gamma}=1.671(589 \mathrm{~nm}), \\
2 V_{\text {calc. }}=68^{\circ}\end{array}$ \\
\hline Colour & Yellow-orange & Yellow & Vivid Green \\
\hline Hardness & 7 & 5 & $3.5-4$ \\
\hline Streak & Yellow-orange & White & White \\
\hline Luster & Vitreous & Vitreous & Vitreous \\
\hline Habit and forms & Anhedral crystals & Euhedral platy prismatic & Mica-like platelets \\
\hline Type locality & $\begin{array}{c}\text { “Costa Balzi Rossi”, } \\
\text { Maremola Creek, Isallo, } \\
\text { Magliolo, Savona, } \\
\text { Liguria, Italy }\end{array}$ & $\begin{array}{c}\text { Rapid Creek, Dawson mining district, } \\
\text { Yukon Territory, Canada }\end{array}$ & $\begin{array}{c}\text { Fillow Quarry, Branchville, } \\
\text { Ridgefield, Fairfield County, } \\
\text { Connecticut, USA }\end{array}$ \\
\hline Associations & $\begin{array}{l}\text { Quartz, (fluorapatite, and possible } \\
\text { graftonite inclusion) }\end{array}$ & $\begin{array}{l}\text { Euhedral quartz and some } \\
\text { "limonite" (former siderite?) }\end{array}$ & $\begin{array}{l}\text { Eosphorite, triploidite, } \\
\text { lithiophilite, quartz }\end{array}$ \\
\hline
\end{tabular}

References: (1) This study; (2) Cámara et al. (2006).

(a)

(b)

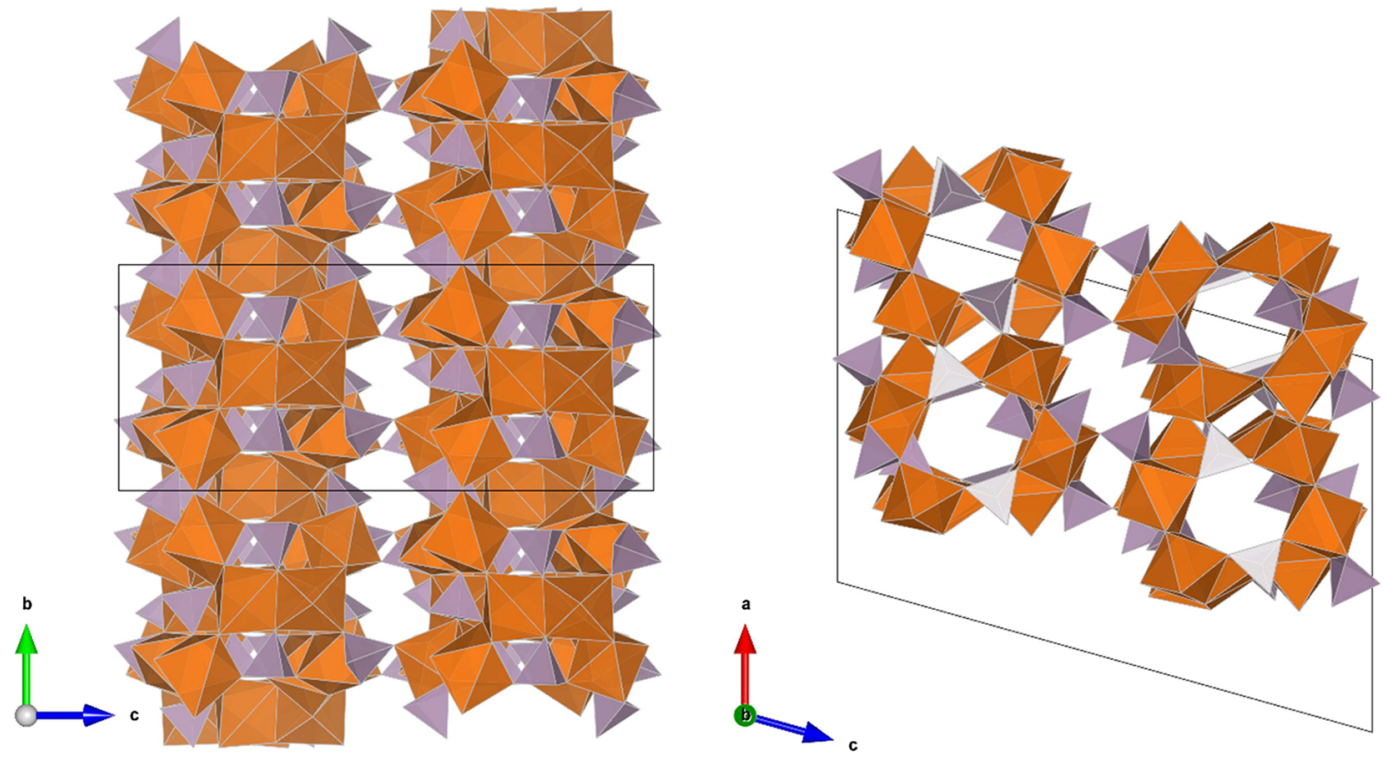

Fig. 4. The four $M_{12} \mathrm{O}_{17}(\mathrm{OH}, \mathrm{F})_{6}\left[\mathrm{PO}_{4}\right]_{10}^{6-}$ units per unit cell. $P 3 \mathrm{a}$,b and $M 1$ tetrahedra, $\mathrm{Al}$ octahedra as well as alkaline site atoms have been removed for the sake of simplicity. Colours as in Fig. 3. Drawing obtained with VESTA 3 (Momma \& Izumi, 2011). 
because lithium content has little effect on its structure stability. The high variability of cation coordination and radius in the arrojadite structure makes it a promising candidate, particularly the Mn-endmember fluordickinsonite( NaNaNa).

Acknowledgements: FC thanks Christian Chopin for involving him in the study of arrojadites, one of the most complex structures FC has dealt with. The paper benefited from the journal reviews made by Frank C. Hawthorne and an anonymous reviewer, and Guest Editor W. Maresch.

\section{References}

Birch, W.D. (2018): Minerals in the arrojadite, alluaudite and jahnsite-whiteite groups from the Mount Wills pegmatite field, Victoria, Australia. Eur. J. Mineral., 30, 635-645.

Boiteau, A. (1971): Un exemple de la tectonique des Alpes Ligures: la région du M. Carmo (Italie). Géologie Alpine I, 47, 117-132.

Bracco, R. \& Marchesini, M. (2016): Le quarziti a lazulite della Liguria e la scoperta della fluorcarmoite-(BaNa). Micro, 14, 68-84.

Bracco, R., Callegari, A., Boiocchi, M., Balestra, C., Armellino, G., Ciriotti, M.E. (2006): Costa Balzi Rossi (Magliolo, Val Maremola, Savona, Liguria): una nuova località per minerali di terre rare e scandio. Micro, 4, 161-178.

Bracco, R., Balestra, C., Odicino, G. (2007): Costa Balzi Rossi e dintorni: un aggiornamento. Prie - Notiziario Mineral. Ligure, 3, 79-97.

Bracco, R., Castellaro, F., Ciuffardi, M., Odicino, G. (2009): Paraniite-(Y) ed altri ritrovamenti da Costa Balzi Rossi. Prie Notiziario Mineral. Ligure, 5, 61-75.

Bracco, R., Balestra, C., Castellaro, F., Mills, S.J., Ma, C., Callegari, A.M., Boiocchi, M., Bersani, D., Cadoni, M., Ciriotti, M.E. (2012): Nuovi minerali di Terre Rare da Costa Balzi Rossi, Magliolo (SV), Liguria. Micro, 10, 66-77.

Brown, I.D. (1981): The bond-valence method: an empirical approach to chemical structure and bonding - Structure and bonding in crystals. Academic Press, New York, NY 1-30.

Cámara, F., Oberti, R., Chopin, C., Medenbach, O. (2006): The arrojadite enigma: I. A new formula and a new model for the arrojadite structure. Am. Mineral., 91, 1249-1259.

Casciani, F.S. \& Condrate, R.A. (1980): The infrared and Raman spectra of several calcium hydrogen phosphates. in "Proceedings - International Congress on Phosphorus Compounds, 2nd (1980)", 175-190.

Castellaro, F. (2014): Chernovite-(Y) a Costa Balzi Rossi. Segnalazioni in breve. Prie, 10, 46.

Černý, P. \& Ercit, S. (2005): The classification of granitic pegmatites revisited. Can. Mineral., 43, 2005-2026.

Chopin, C., Oberti, R. \& Cámara, F. (2006): The arrojadite enigma: II. Compositional space, new members and nomenclature of the group. Am. Mineral., 91, 1260-1270.

Cortesogno, L. (1984): Metamorfismo e magmatismo prealpini nel basamento e nel tegumento delle Alpi Liguri. Mem. Soc. Geol. Ital., 28, 79-94. (in Italian).

Cortesogno, L., Galbiati, B., Principi, G. (1987): Note alla "Carta geologica delle ofioliti del Bracco" e ricostruzione della paleogeografia Giurassico-Cretacica. Ofioliti, 12, 261-342.

Della Ventura, G., Bellatreccia, F., Radica, F., Chopin, C., Oberti, R. (2014): The arrojadite enigma III. The incorporation of volatiles: a polarised FTIR spectroscopy study. Eur. J. Mineral., 26, 679-688.
Demartin, F., Gramaccioli, C.M., Pilati, T., Sciesa, E. (1996): Sigismundite, $(\mathrm{Ba}, \mathrm{K}, \mathrm{Pb}) \mathrm{Na}_{3}(\mathrm{Ca}, \mathrm{Sr})(\mathrm{Fe}, \mathrm{Mg}, \mathrm{Mn})_{14} \mathrm{Al}(\mathrm{OH})_{2}\left(\mathrm{PO}_{4}\right)_{12}$, a new Ba-rich member of the arrojadite group from Spluga Valley, Italy. Can. Mineral., 34, 827-834.

Eagle, R.M., Birch, W.D., McKnight, S. (2015): Phosphate minerals in granitic pegmatites from the Mount Wills district, NorthEastern, Victoria. Proc. R. Soc. Vic., 127, 55-68.

Fisher, D.J. (1965): Dickinsonites, fillowite and alluaudites. Am. Mineral., 50, 1647-1669.

Frost, R.L., Xi, Y., Scholz, R., Horta, L.F.C. (2013): The phosphate mineral arrojadite-(KFe) and its spectroscopic characterization. Spectrochim. Acta A, 109, 138-145.

Gagné, O.C. \& Hawthorne, F.C. (2015): Comprehensive derivation of bond-valence parameters for ion pairs involving oxygen. Acta Crystallogr. B, 71, 562-578.

Gunter, M.E., Downs, R.T., Bartelmehs, K.L., Evans, S.H., Pommier, C.J.S., Grow, J.S., Sanchez, M.S., Bloss, F.D. (2005): Optic properties of centimeter-sized crystals determined in air with the spindle stage using EXCALIBRW. Am. Mineral., 90, 1648-1654.

Hawthorne, F.C. (1983): Graphical enumeration of polyhedral clusters. Acta Crystallogr. A, 39, 724-736.

- (1994): A bond-topological approach to theoretical mineralogy: crystal structure, chemical composition and chemical reactions. Phys. Chem. Minerals, 39, 841-874.

Hawthorne, F.C., Ungaretti, L., Oberti, R. (1995): Site populations in minerals; terminology and presentation of results of crystalstructure refinement. Can. Mineral., 33, 907-911.

Horiba Jobin Yvon GmbH (2004, 2005): LabSpec [Software for Raman spectroscopic data analysis, acquisition and manipulation]. Version 5.64.15.

Kallfaß, C., Hoch, C., Schier, H., Simon, A., Schubert, H. (2010): The transition metal-rich orthophosphate arrojadite with special structural features. Z. Naturforsch B. 65b, 1427-1433.

Kallfaß, C., Hoch, C., Schier, H., Wituchowski, C., Görke, O., Schubert, H. (2011): The ortho-phosphate arrojadite as a new material for cathodes in Li-ion batteries. in "Materials Challenges in Alternative and Renewable Energy: Ceramic Transactions", G. Wicks, J. Simon, R. Zidan, E. Lara-Curzio, T. Adams, J. Zayas, A. Karkamkar, R. Sindelar \& B. Garcia-Diaz, eds. John Wiley \& Sons Inc, Hoboken, NJ, USA.

Krutik, V.M., Pushcharovskii, D.Y., Pobedimskaya, E.A., Belov, N.V. (1979): Crystal structure of arrojadite. Kristallografiya, 24, $743-750$

Larson, A.C. \& Von Dreele, R.B. (1994): General Structure Analysis System (GSAS). Los Alamos National Laboratory Report LAUR. 86-748.

Lindberg, M.L. (1950): Arrojadite, hühnerkobelite, and graftonite. Am. Mineral., 35, 59-76.

Mandarino, J.A. (2007): The Gladstone-Dale compatibility of minerals and its use in selecting mineral species for further study. Can. Mineral., 45, 1307-1324.

Marinova, D., Kostov, V., Nikolova, R., Kukeva, R., Zhecheva, E., Sendova-Vasileva, M., Stoyanova, R. (2015): From kröhnkiteto alluaudite-type of structure: novel method of synthesis of sodium manganese sulfates with electrochemical properties in alkali-metal ion batteries. J. Mater. Chem. A, 3, 2228722299.

Menardi Noguera, A. (1984): Nuove osservazioni sulla struttura del Massiccio del Monte Carmo (Alpi Liguri). Boll. Soc. Geol. Ital., 103, 189-203.

Merlino, S., Mellini, M., Zanazzi, P.F. (1981): Structure of arrojadite, $\mathrm{KNa}_{4} \mathrm{CaMn}_{4} \mathrm{Fe}_{10} \mathrm{Al}\left(\mathrm{PO}_{4}\right)_{12}(\mathrm{OH}, \mathrm{F})_{2}$. Acta Crystal$\log r . B, 37,1733-1736$.

Momma, K. \& Izumi, F. (2011): VESTA 3 for three dimensional visualization of crystal, volumetric and morphology data. $J$. Appl. Crystallogr., 44, 1272-1276. 
Moore, P.B., Araki, T., Merlino, S., Mellini, M., Zanazzi, P.F. (1981): The arrojadite-dickinsonite series, $\mathrm{KNa}_{4} \mathrm{Ca}(\mathrm{Fe}$, $\left.\mathrm{Mn}^{2+}\right)_{14} \mathrm{Al}(\mathrm{OH})_{2}\left(\mathrm{PO}_{4}\right)_{12}$ : crystal structure and crystal chemistry. Am. Mineral., 66, 1034-1049.

Oliver, W.C. \& Pharr, G.M. (1992): An improved technique for determining hardness and elastic modulus using load and displacement sensing indentation experiments. J. Mater. Res., 7, 1564-1583.

—, - (2004): Measurement of hardness and elastic modulus by instrumented indentation: Advances in understanding and refinements to methodology. J. Mater. Res., 19, 3-20.

Pouchou, J.L. \& Pichoir, F. (1984): A new model for quantitative analysis: Part I. Application to the analysis of homogeneous samples. La Recherche Aérospatiale, 3, 13-38.

—, - (1985): 'PAP' $\varphi(\rho \mathrm{Z})$ procedure for improved quantitative microanalysis. in "Microbeam Analysis", J.T. Armstrong, ed. San Francisco Press, San Francisco, CA, USA, 104-106.

Robertson, B.T. (1982): Occurrence of epigenetic phosphate minerals in a phosphatic iron-formation, Yukon Territory. Can. Mineral., 20, 177-187.

Robinson, G.W., Van Velthuizen, J., Ansell, H.G., Sturman, B.D. (1992): Mineralogy of the Rapid Creek and Big Fish River area, Yukon Territory. Mineral. Rec., 23, 1-47.

Sheldrick, G.M. (2008): A short history of SHELX. Acta Crystallogr. A, 64, 112-122.

Smith, D.G.W. \& Nickel, E.H. (2007): A system for codification for unnamed minerals: report of the Subcommittee for Unnamed Minerals of the IMA Commission on New Minerals, Nomenclature and Classification. Can. Mineral., 45, 983-1055.

Spek, A.L. (2009): Structure validation in chemical crystallography. Acta Crystallogr. D, 65, 148-155.

Števko, M., Uher, P., Sejkora, J., Malíková, R., Škoda, R., Vaculovič, T. (2015): Phosphate minerals from the hydrothermal quartz veins in specialized S-type granites, Gemerská Poloma (Western Carpathians, Slovakia). J. Geosci., 60, 237-249.
Števko, M., Sejkora, J., Uher, P., Cámara, F., Škoda, R. Vaculovič, T. (2018): Fluorarrojadite-(BaNa), $\mathrm{BaNa}_{4} \mathrm{CaFe}_{13} \mathrm{Al}$ $\left(\mathrm{PO}_{4}\right)_{11}\left(\mathrm{PO}_{3} \mathrm{OH}\right) \mathrm{F}_{2}$, a new member of the arrojadite group from Gemerská Poloma, Slovakia. Mineral. Mag., 82, 863-876.

Strunz, H. \& Nickel, E.H. (2001): Strunz Mineralogical Tables. Chemical Structural Mineral Classification System, 9th edition. E. Schweizerbart, Stuttgart, Germany, 870 p.

Su, S.C., Bloss, F.D., Gunter, M.E. (1987): Procedures and computer programs to refine the double variation method. Am. Mineral., 72, 1011-1013.

Tomes, H.E., Di Cecco, V.E., Tait, K.T., Cámara, F. (2018): Crystal structure of near-endmember Arrojadite-(BaNa) from Big Fish River, Yukon, Canada. Can. Mineral., 56, 1-16.

Trad, K., Carlier, D., Croguennec, L., Wattiaux, A., Ben Amara, M., Delmas, C. (2010): $\mathrm{NaMnFe}_{2}\left(\mathrm{PO}_{4}\right)_{3}$ alluaudite phase: synthesis, structure, and electrochemical properties as positive electrode in lithium and sodium batteries. Chem. Mater., 22, 5554-5562.

Vignola, P., Hatert, F., Baijot, M., Dal Bo, F., Andò, S., Bersani, D., Pavese, A., Risplendente, A., Vanini, F. (2016): Arrojadite(BaNa), $\quad \mathrm{BaNa}_{3}(\mathrm{Na}, \mathrm{Ca}) \mathrm{Fe}_{13}^{2+} \mathrm{Al}\left(\mathrm{PO}_{4}\right)_{11}\left(\mathrm{PO}_{3} \mathrm{OH}\right)(\mathrm{OH})_{2}$, a new phosphate mineral from the Luna albite pegmatite, Dorio commune, Lecco Province, Italy. Can. Mineral., 54, 1021-1032.

Wojdyr, M. (2010): Fityk: a general-purpose peak fitting program. $J$. Appl. Crystallogr., 43, 1126-1128.

Wolfe, C.W. (1941): The unit cell of dickinsonite. Am. Mineral., 26, $338-342$.

Young, F.G. \& Robertson, B.T. (1984): The Rapid Creek Formation: An Albian flysch-related phosphatic iron formation in northern Yukon Territory. Can. Soc. Pet. Geol. Special Publ. Mem., 9, 361-372.

Received 4 March 2019

Modified version received 2 May 2019

Accepted 3 May 2019 